Barker, P.F., Camerlenghi, A., Acton, G.D., et al., 1999

Proceedings of the Ocean Drilling Program, Initial Reports Volume 178

\title{
2. An Approach to Antarctic Glacial History: THE AIMS OF LEG 178'
}

\author{
P.F. Barker ${ }^{2}$ and A. Camerlenghi ${ }^{3}$
}

Ocean Drilling Program (ODP) Leg 178 was proposed partly as an examination of Antarctic Peninsula glacial history and partly as a test of the strategy of determining this history by sampling glacially transported sediments at the continental margin. If successful, it could lead to a program of two or three other legs around Antarctica that, in combination, might determine the long-term history of the entire Antarctic Ice Sheet. Leg 178 also had a second objective: to obtain a long, highresolution record of Holocene climate from Palmer Deep, an isolated deep basin on the inner continental shelf.

The proposal that became Leg 178 was therefore based on several assumptions, described below. Briefly, they are:

1. The Antarctic Ice Sheet is now and has been throughout its existence an important component of the Earth's climate engine, which it is necessary to document and understand.

2. An understanding of the ice sheet's function and what controls its development cannot be obtained until its history is known.

3. Existing knowledge of Antarctic glacial history, derived largely from sparse onshore data and low-latitude climate proxies, is inadequate and ambiguous; the proxies themselves disagree. Furthermore, continued use of the same proxies and onshore data is unlikely to resolve present ambiguities and disputes.

4. The unsorted sediments transported beneath the ice sheet to the outer continental shelf and slope, and their derivatives in sediment drifts on the continental rise, contain complementary records of ice-sheet history that are accessible to drilling. The shelf/slope record is direct but relatively crude (discontinuous and difficult to recover). The rise drift record is continuous, high

${ }^{1}$ Examples of how to reference the whole or part of this volume. ${ }^{2}$ British Antarctic Survey, High Cross, Madingley Road, Cambridge CB3 OET, United Kingdom. p.barker@bas.ac.uk ${ }^{3}$ Osservatorio Geofisico Sperimentale, P.O. Box 2011, Trieste Opicina 34016, Italy. 
resolution, and easier to recover but is indirect, and therefore needs the shelf record to aid its interpretation.

5. By sampling this record in three or four places around Antarctica and by combining the data from different places using numerical models of ice-sheet behavior, it should be possible to obtain a direct estimate of ice-sheet history.

6. The Antarctic Peninsula is the best place to begin because both sediment distribution and the glacial environment are well defined there. Also, glacial history is probably relatively short. There is the opportunity to refine the technique and understand the depositional environments better before tackling what might be a more difficult margin elsewhere.

7. By elucidating Antarctic glacial history, drilling will encourage studies of the causes of glaciation and will simplify the future interpretation of proxy data (in particular, studies of global eustatic sea-level change, for which variations in grounded ice volume remain the one generally accepted rapid-action, repeatable cause).

This strategy was proposed by the Antarctic Offshore Acoustic Stratigraphy initiative (ANTOSTRAT, a group comprising mainly seismic stratigraphers and marine geologists working around the Antarctic margin), reviewed and adopted by an ODP Detailed Planning Group, reviewed further by thematic panels, and formally endorsed by the JOIDES Planning Committee (now Science Committee/Operations Committee). Despite the additional cost of an ice support ship and the inflexibility of the Antarctic ice and weather window, the proposed strategy has led to the drilling program described here that, if successful, will in turn lead to drilling in Prydz Bay and elsewhere around the Antarctic margin.

In this introduction to the objectives, activities, and achievements of Leg 178 drilling, we set out the regional tectonic environment, what is known of past and present Antarctic climate and ocean circulation, and an account of predrilling knowledge of the depositional environments that we aimed to sample during the leg. We include also a brief account of the longer term rationale for drilling, showing how the results of drilling at three or four locations around Antarctica, coordinated through numerical models, might elucidate Antarctic glacial history.

\section{ANTARCTIC ICE-SHEET HISTORY}

The Antarctic Ice Sheet is today and has been for several million years a major component of the global climate system, responsible for deep- and bottom-water formation and eustatic sea-level change. It is also a source of "noise" in the oxygen isotopic record, which limits the value of that record to other studies through most of the Cenozoic.

At present, the history of the Antarctic Ice Sheet is unknown: it has been inferred from low-latitude proxy data-principally from oxygen isotopic measurements on deep-ocean benthic foraminifers-and from the record of eustatic sea-level change adduced from sediments on lowlatitude margins (e.g., Miller et al., 1987; Haq et al., 1987). However, these inferences are both ambiguous and in disagreement (e.g., Sahagian and Watts, 1991; Barker, 1992), which not only leaves the history unresolved but also limits the credibility and usefulness of both sets of proxy data. For example, there is a dispute over whether the principal increases in Antarctic ice volume, affecting the benthic isoto- 
pic record, occurred at $\sim 35 \mathrm{Ma}$, at $16-13 \mathrm{Ma}$, or only after $\sim 3 \mathrm{Ma}$. Within these various hypotheses, assumptions have to be made about the constancy of equatorial surface temperatures, or the high-latitude surface origins and temperatures of intermediate to deep waters at low latitudes, that may be incorrect. Similarly, changes in grounded ice volume provide the only generally accepted repeatable, rapid-acting cause for global eustatic sea-level change, yet the timing and amplitudes of sea-level change adduced from low-latitude margin sediments are disputed. Additionally, changes occur at times when there is no independent evidence for the existence of substantial volumes of grounded ice on Antarctica or elsewhere. Further, the isotopic and sea-level estimates of grounded ice volume disagree substantially with each other, at both long and short periods, through most of the Cenozoic. Other proxies (bottom-water formation and ice-rafted detritus) are less useful because, although they are certainly produced directly by the present ice sheet, their relationship with ice volume changes is much less direct and is easy to misinterpret. Onshore Antarctic evidence of glacial history is sparse and at present controversial; the argument continues as to how stable the Antarctic Ice Sheet has been (e.g., Webb and Harwood, 1991; Denton et al., 1993; Barrett, 1996).

The opportunities for learning more about ice-sheet history are limited. Deep and intermediate waters of the Southern Ocean have generally been corrosive to the carbonate tests almost exclusively used in isotopic analysis, so the problems of indirect estimates of ice volume from distal proxy data will persist. Some progress may be made by detailed analysis at very high resolution of carbonate sections from a large number of lower latitude sites, but the solutions will remain ambiguous. Other proxies, and the onshore geological record, seem unlikely to be able to help. However, the Antarctic margin sediments hold a direct record of Antarctic ice-sheet fluctuation that can help resolve the ambiguities of ice-volume change and clear the way for more useful interpretation of isotopic and sea-level data in the future.

The long-term aim of the suite of linked ANTOSTRAT drilling proposals, reviewed and adopted by the Detailed Planning Group, is to provide an estimate of variations in the size of the Antarctic Ice Sheet through the Cenozoic. This will necessarily include periods when the ice sheet was much smaller and warmer than it is today, reaching the margin only occasionally and in a few places, with significant fluvial sediment transport and deposition elsewhere. It is therefore necessary for drilling to sample both East and West Antarctic glacial history and to distinguish a small interior ice sheet, barely reaching the margin, from a much larger ice sheet with a large coastal ice budget. This means making use of numerical models to suggest what might have been the patterns of past glaciation and drilling in different regions, as the models or other relevant information might suggest. For example, Figure F1 (from Huybrechts, 1993) shows a glaciological model of ice sheets that cover only parts of the continent during warmer conditions. It is clear that some regions will be more sensitive to particular stages of ice-sheet volume change than others and that no single region will provide a complete history. The models provide the means of combining data from different regions of the Antarctic margin into a complete history of ice-sheet development. For a particular region (areas where proposals are or will be focused are starred in Fig. F1), it will be important to establish when the ice sheet first arrived at the margin, when there were changes in the rate of ice transport to the margin (that might have influenced both the size of the particular ice catchment and the geome-
F1. Dependence of ice-sheet volume upon mean annual temperature (K) at sea level, p. 29.
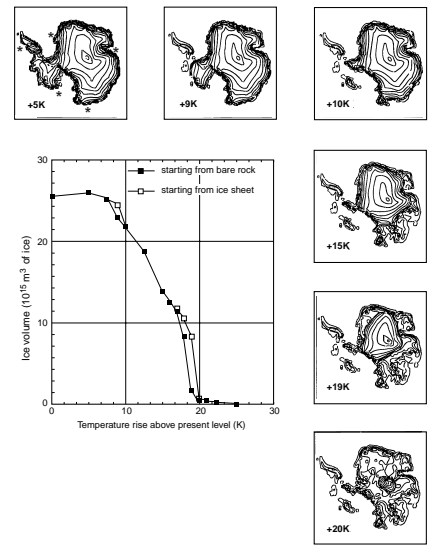
try of sedimentation), and what was the sensitivity of ice in this region to Milankovich-scale change. The record of these events and sensitivities lies within glacially transported sediments deposited at the margin and is in most cases accessible to drilling.

\section{Antarctic Glacial Sediments}

Great strides have been made in recent years in the collaborative interpretation of seismic data from the Antarctic margin through the ANTOSTRAT initiative (see Cooper et al., 1994, 1995; Barker and Cooper, 1997). Together with the simplicity of the modern Antarctic glacial regime (compared with that of the Arctic), these advances have led to the rapid emergence and application of a unifying model of glacial sediment transport and deposition (Alley et al., 1989; Larter and Barker, 1989; Bartek et al., 1991; Cooper et al., 1991; Kuvaas and Kristoffersen, 1991). Briefly, almost all ice transport to the ice-sheet margins takes place within broad, rapidly moving ice streams. Rapid flow is enabled by low-friction basal conditions, whose main source is the existence of an overpressured and undercompacted, unsorted, shearing basal till. The necessary shear ensures that ice transport is accompanied by till transport, and virtually all of the transported till is melted out, dropped, and deposited very close to the grounding line, where the ice sheet becomes ice shelf before calving into icebergs and drifting north. The ice stream therefore essentially erodes and transports inshore of the grounding line and deposits directly offshore in a high-latitude analogue of the low-latitude subaerial erosion/shoreline/marine sedimentation system (the level of erosion, however, is not sea level but the icestream base). Further, the grounding line advances and retreats under the influence of upstream ice provision and basal sediment supplyand sea-level change-that are all related to climate. The very large prograded sediment wedges beneath the Antarctic margin were developed during a series of glacial maxima, when the ice sheet was grounded all the way to the continental shelf edge (Fig. F2).

The glacial sedimentation regime has other characteristics. Shelfedge progradation is usually focused into broad "trough-mouth fans" opposite the main ice streams, and the shelf is overdeepened (generally to between 300 and $600 \mathrm{~m}$ depth, but in places much deeper) and inward sloping. Continental slopes are often steep, and in places turbidity current transport of the unstable component of slope deposition (with downcurrent deposition of suspended fines) has produced large, mainly pelagic/hemipelagic sediment drifts on the continental rise (Kuvaas and Leitchenkov, 1992; Rebesco et al., 1996, 1997; Escutia et al., 1997; Fig. F3). Sediment supply to the slope and rise is highly cyclic, with large quantities of unsorted diamicton deposited during glacial maxima and very little during interglacial periods.

Three depositional environments are recognized: shelf topsets and slope foresets of the prograded wedge and proximal hemipelagic drifts on the continental rise. Of these, the shelf record is potentially the least continuous. There, sediment is preserved mainly as a result of slow subsidence from cooling and from flexural response to the topset and foreset load. The sediment is prone to re-erosion during the next glacial advance. The topsets tend to mark only the major changes in glacial history so that the more continuous foreset record is an essential complement. The proximal rise drifts may not always be present and are as yet sparsely sampled, but potentially they contain an excellent record, closely related to that of the upper slope foresets from which they are
F2. Sequence model of deposition on shelf and slope through a glacial cycle, p. 30.

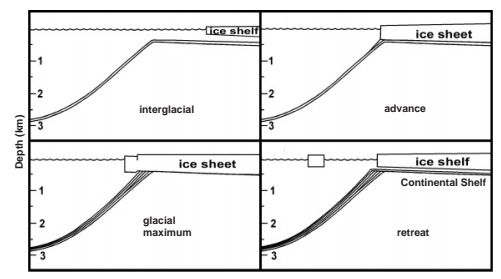

F3. Schematic drawing of the processes active during glacial halfcycles, p. 31.

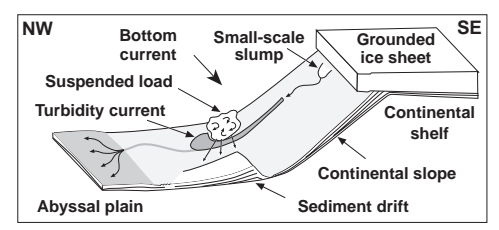


largely derived. Existing seismic data and drill sites from around Antarctica have demonstrated the coarse (but not as yet the fine-scale) climate record in continental rise sediments and the likely climatic sensitivity of margin wedge geometry (Barker, 1995a). These sites have also revealed the partial nature of the shelf topset record (Hayes, Frakes, et al., 1975; Barron, Larsen, et al., 1989).

The continental shelf is an area of high biogenic productivity during interglacial periods. Although long-term sediment preservation on the shelf is limited by the erosional effects of grounded ice sheets during subsequent glacials, biogenic interbeds are preserved within sequence groups composed mainly of thick glacial diamicton topsets and foresets. In addition, glacially eroded deeps can preserve expanded Holocene sections that may be continuous and essentially biogenic, if the ice-sheet grounding line is sufficiently remote that ice-rafted debris is minor or absent and the sections are well protected from bottomcurrent action. Such sections can provide a record of decadal and millennial variability that can be compared with high-resolution records from low latitudes and from the ice sheet itself. This environment is available on the inner shelf of the Antarctic Peninsula at Palmer Deep (Domack and McClennen, 1996; Leventer et al., 1996) and was sampled during Leg 178.

\section{Regional Features of Antarctic Glaciation}

Different parts of Antarctica have had different glacial histories, as the numerical models of ice-sheet development (e.g., Fig. F1) suggest. The present Antarctic Ice Sheet comprises an East Antarctic component grounded largely above present sea level and a West Antarctic component grounded mostly below sea level. Marine-based (West Antarctic) ice sheets are considered less stable. There is evidence from around Antarctica that, although East and West Antarctic climates were coupled in the past, changing approximately in phase, the climate of West Antarctica (including the Antarctic Peninsula) has varied about a consistently warmer baseline (e.g., Kennett and Barker, 1990; Wise et al., 1992). Although East Antarctic glaciation extends to 35 Ma or earlier, West Antarctic glaciation probably began more recently, during generally colder times. Further, there is strong evidence that Northern Hemisphere glaciation has been the main contributor to global sea-level change over the past $0.8 \mathrm{~m}$.y. (and probably $2.5 \mathrm{~m}$.y.) and has therefore partly driven the more subdued changes in Antarctic glaciation. Another significant local control may have been the Transantarctic Mountains, which probably attained much of their present elevation and influence on the East Antarctic Ice Sheet during late Cenozoic time. The Antarctic Peninsula has many specific glacial and paleoglacial features but has also a unique regional tectonic environment that both constrains and enhances the opportunities for drilling.

\section{ANTARCTIC PENINSULA}

\section{Topography and Climate}

The Antarctic Peninsula is a long, dissected plateau giving the impression of a peneplain. It stands at $\sim 900 \mathrm{~m}$ elevation at its northern end $\left(63.5^{\circ} \mathrm{S}\right)$, rising to $1750 \mathrm{~m}$ at $64^{\circ} \mathrm{S}$ and remaining between that altitude and $2000 \mathrm{~m}$ as far as $68.3^{\circ} \mathrm{S}$ (Elliot, 1997). The crest is broader in 
the south but is everywhere dissected to varying degrees by steep-sided fjords and glacial valleys. Ice cover is variable, a few hundred meters thick at most, and does not extend far beyond the central plateau on the Pacific side; it drains rapidly through steep ice-falls and short valley glaciers to sea level at the heads of fjords (Fig. F4). Ice shelves are small and sparse, and few large icebergs are produced. The dissected central plateau is bordered by longitudinal fjords and islands (some with elevations matching those of the mainland) conveniently regarded as forming an inner continental shelf. This region is floored by hard rock, whereas the middle shelf is mainly softer rock (partly sediments and probably preglacial), and the outer shelf is underlain by till. A topographic high separates the middle and outer shelf. In the south, near Alexander Island, the distance from plateau crest to continental shelf edge is $600 \mathrm{~km}$, tapering to $200 \mathrm{~km}$ in the north. This distance is the maximum possible extent of the ice catchment, and more than half of it is now submarine (Fig. F5).

The greatest relief is in the inner-shelf region: fjords reach water depths $>1000 \mathrm{~m}$ and are assumed to have been overdeepened by grounded ice. Relief on the outer and middle shelf is far less, but the shelf is essentially inward sloping. Shelf edge depths range from $300 \mathrm{~m}$ to $>500 \mathrm{~m}$. Between $70^{\circ} \mathrm{S}$ and $63^{\circ} \mathrm{S}$ the continental slope is steep, reaching $17^{\circ}$ in places.

To the northeast lies Bransfield Strait, a linear trough separating the South Shetland Islands from the Antarctic Peninsula mainland, which reaches depths exceeding $2000 \mathrm{~m}$ and contains active volcanoes. Unlike other areas, the continental shelf of the South Shetland Islands is narrow and has shallow depths $(\sim 200 \mathrm{~m})$. Opposite the South Shetland Islands lies the South Shetland Trench, at a depth of $\sim 4700 \mathrm{~m}$.

Snow accumulation varies with temperature and is greatest around the continental edge, particularly along the Antarctic Peninsula, which is warmer than East Antarctica. The Antarctic Peninsula acts as a major barrier to tropospheric circulation, and its ice sheet currently receives almost four times the average Antarctic continental snowfall (Reynolds, 1981; Drewry and Morris, 1992). However, modern meltwater-influenced sediments are known only from the South Shetland Islands (Banfield and Anderson, 1995), and the climatic regime elsewhere is fully polar. Snow accumulation governs the rates of ice transport required to maintain mass balance, hence the rate of basal sediment transport; greater accumulation means an expanded sediment record. There is much evidence (below) that grounded ice regularly reached the continental shelf edge during glacial maxima, although the level of precipitation at that time is unknown. In all, it seems reasonable to characterize the Antarctic Peninsula climatic regime, through a late Pleistocene glacial cycle, as a fully glacial, high-relief, high-precipitation, small-reservoir regime, with a rapid response to sea-level and climate change and an expanded sedimentary record.

\section{Regional Oceanography}

Present-day regional oceanography is fairly well known. A western boundary current, partly wind driven but containing elements originating in the Weddell Sea, was postulated to flow along the continental margin from northeast to southwest (Gordon, 1966; Heezen and Hollister, 1971) and has since been verified by direct-current meter measurements (Nowlin and Zenk, 1988; Camerlenghi et al., 1997a). Over a 10month period, flow across the sediment drifts on the continental rise
F4. Head of Lallemand Fjord showing flat, possibly peneplanated Antarctic Peninsula plateau, p. 32 .

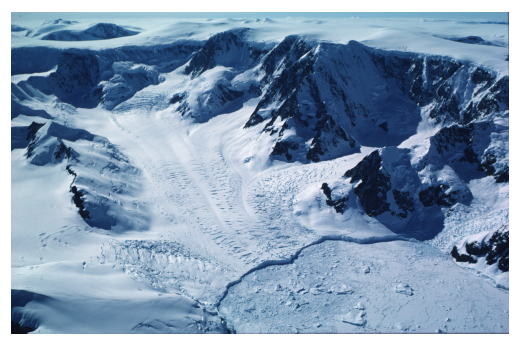

F5. Bathymetric chart of the Antarctic Peninsula Pacific margin with Leg 178 sites marked, p. 33.

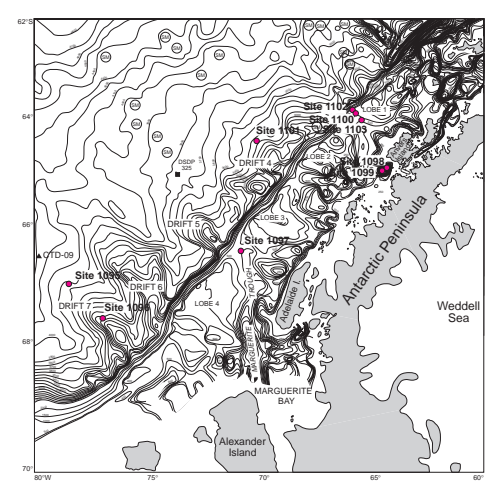


was slow and steady; mean current speeds were $\sim 6 \mathrm{~cm} / \mathrm{s}$ at depths of 3475 and $3338 \mathrm{~m}$ on the flanks of one drift, and the speed never exceeded $20 \mathrm{~cm} / \mathrm{s}$ (Camerlenghi et al., 1997a). These speeds are enough to maintain fine silt and clay in suspension but are too weak to cause significant erosion on the rise (Pudsey and Camerlenghi, 1998). Flow directions ( $8 \mathrm{~m}$ above the seabed) were parallel to isobaths, and potential temperatures at these depths averaged $0.11^{\circ}$ and $0.13^{\circ} \mathrm{C}$, respectively, suggesting (in combination with other data) an origin in Weddell Sea Deep Water (WSDW). There is no direct evidence (beyond the sediments themselves) of glacial-age current strength, but Pudsey (1992) has demonstrated a reduced WSDW flow during the Last Glacial Maximum (LGM).

Farther north lies the axis of the east-flowing Antarctic Circumpolar Current (ACC) and Polar Front (e.g., Orsi et al., 1995). The ACC is of higher energy, and eddies are common. However, there is no indication that the ACC or Polar Front has extended so far south in the recent past. The drill sites on the rise lie beneath the Circumpolar Deep Water (CDW), and temperature-depth sections such as that of Figure F6 are typical. Surface-water temperatures range up to $+1^{\circ} \mathrm{C}$ during the summer, and seasonal sea ice cover above the rise sites lasts for 6 to 9 months on average (Gloersen and Campbell, 1992).

Sea ice cover is more extensive on the continental shelf than on the rise, although coastal polynyas may occur (Zwally et al., 1985; Gloersen and Campbell, 1992). Measurements on the continental shelf in this part of the Antarctic Peninsula (Hoffmann et al., 1996) are largely confined to static hydrographic measurements of temperature and salinity (some dissolved oxygen and sparse drifting buoy data). Shelf water belongs to the CDW. Surface currents on the shelf are mainly toward the southwest. On the basis of sparse data, Hoffmann et al. (1996) hypothesize a slow southwest shelf current with a northeast countercurrent offshore, forming a weak local gyre. Icebergs are sparse in this region, and pack ice was not expected at the time of drilling.

\section{Geology and Tectonics}

The tectonic setting of the Antarctic Peninsula is unusual but straightforward. Its onshore geology is a mixture of calc-alkaline plutonic and volcanic rocks, metasediments of an old accretionary prism, and gneissic basement, reflecting a long history of subduction at the Pacific margin of Gondwana (e.g., Adie, 1954, 1955; Saunders et al., 1980; Garrett and Storey, 1987; Barker et al., 1991; Moyes et al., 1994; Leat et al., 1995). A young accretionary prism is not exposed onshore, and the youngest exposed sediments are terrigenous and volcaniclastic sediments of mainly late Mesozoic age (Paleogene on the backarcWeddell Sea margin).

Subduction of the Pacific Ocean floor at this margin for more than 150 m.y. ended with the progressive subduction (collision) of segments of the Phoenix-Antarctic ridge crest at the trench, earliest $(\sim 50 \mathrm{Ma})$ in the southwest and latest (3-6 Ma) in the northeast (Barker, 1982; Larter and Barker, 1991a; Fig. F7). The geometry of ridge-crest subduction is very well known because the trailing flank of the ridge crest belonged to the Antarctic plate. This meant that motion relative to the margin was zero after collision and that the trailing flank survived at the seafloor. The observed half-spreading rate was half the subduction rate, and (until a very late stage) the spreading fabric was parallel and perpendicular to the margin. The ridge-crest subduction event is helpful to
F6. CTD temperature and salinity profile, station CTD-09, with water masses labeled, p. 34.

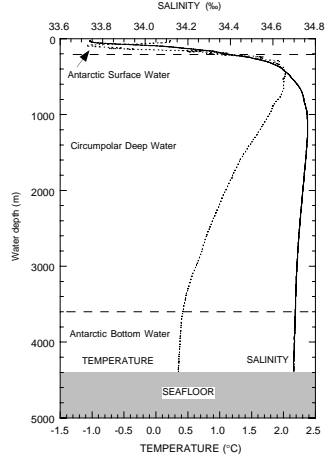

F7. Ages of ocean floor and ridge crest-trench collisions along the Antarctic Peninsula Pacific margin, p. 35.

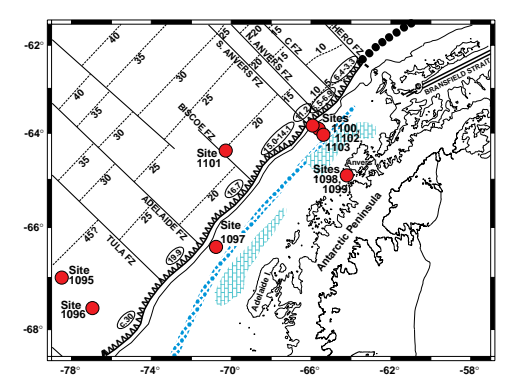


the preservation and study of margin sediments; the series of young ocean floor ages along the margin places constraints on the ages of overlying sediments that may be traced onto the shelf and rise (Larter and Barker, 1991b; Rebesco et al., 1997). In the collision segment, there was uplift of the outer margin for a few million years after subduction as the forearc above the subsiding ridge crest was heated. The resulting hiatus in terrigenous sediment provision to a corresponding section of the continental rise was recorded at Deep Sea Drilling Project (DSDP) Site 325 (Hollister, Craddock, et al., 1976). It is marked in seismic reflection profiles by the restricted range of a particular depositional unit on the shelf (S3 of Larter and Barker, 1991b) and by likely gaps in terrigenous deposition on the rise (Rebesco et al., 1997). Importantly, however, it is wholly after the time of collision; the continuity of terrigenous supply for 2-3 m.y. before collision (filling and crossing the approaching mid-ocean ridge crest) is shown by a broad zone of very low oceanic magnetic anomaly amplitudes (a "magnetic quiet zone"; Larter and Barker, 1991a) along the margin. The age range of the interval of reduced terrigenous sediment supply is diachronous along the margin, following the progress of the collision itself.

In the far northeast the remaining Phoenix-Antarctic ridge segments ceased spreading 3-4 m.y. ago before reaching the subduction zone, at about the time of the youngest collision. Thus, the South Shetland Trench survives at the seabed. It is considered that subduction continues, accompanied by rollback of the subduction hinge and active backarc extension in Bransfield Strait (Barker and Dalziel, 1983; Barker and Austin, 1994, 1998; Fig. F7).

The middle and outer continental shelves are separated by a midshelf high (MSH), best seen by its gravity signature (Fig. F8). This feature is considered to have been a mid-slope high during subduction (Larter and Barker, 1991b; Bart and Anderson, 1995; Larter et al., 1997), and probably marked the edge of the rigid overriding plate: such positive features are common at subducting margins (e.g., Fryer, Pearce, et al., 1990; Taylor, Fujioka, et al., 1990; Barker, 1995b). The MSH may be of continental origin (it is generally nonmagnetic) or may have a serpentinite composition as in the Marianas arc. Thermal uplift after ridgecrest subduction seems to have been focused on the MSH. Inshore from the MSH lies a series of shelf basins, interpreted as precollision upper forearc basins with a gently dipping, possibly depositional inner flank, but an outer flank probably deformed during uplift of the MSH (Fig. F9). They could be Cretaceous or Cenozoic (precollision) in age, with a mixed terrigenous/biogenic composition. These basins and the MSH are prime sources of reworked material within the glacial sediments of the prograded wedge.

\section{Tectonics and Sedimentation}

Two instances of the influence of tectonics on sedimentation along the margin have already been mentioned. First, the ages of young ocean floor at the margin in the northeast constrain the age of overlying sediments, aiding the location of appropriate sites for drilling. Second, thermally driven uplift of the middle shelf immediately after ridge-crest collision prevented the supply of terrigenous sediment to a section of the continental rise. Slow subsidence thereafter is marked by basal onlap of the shelf Sequence S3 (below), diachronously along the margin. In planning the drill sites it was necessary to try to avoid examining the onset of a glacial regime, on the continental shelf or on the
F8. GEOSAT GM mission satellitederived free-air gravity map of the Antarctic Peninsula and southeast Pacific, p. 36.

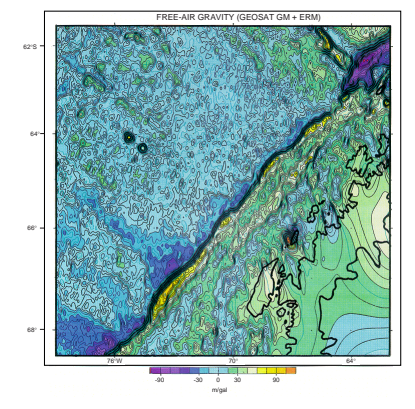

F9. Inner-shelf basin in Lobe 1 area, on seismic profile AI95-149, with mid-shelf high to the northwest, p. 37.

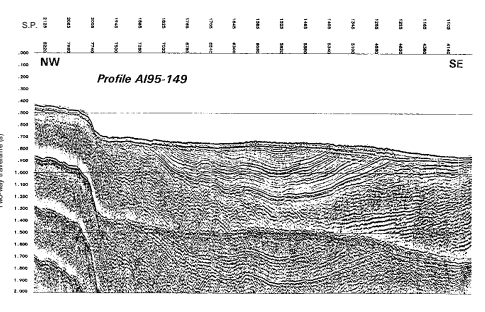


rise, where this diachronous, tectonics-driven break in terrigenous sedimentation might confuse a climate-driven change. This meant sampling only the younger sediments in the northeast and the older sediments in the southwest.

Tectonics has influenced sedimentation in other ways. Following ridge-crest subduction, the margin has resembled thermally a young extensional margin. Preservation of topsets of the shelf-slope prograded wedge has been assisted by thermal subsidence; on much older margins, this mechanism is far less effective. Also, the isostatic response to sediment load is more local in a younger margin, making it easier to detect and use. Further, it has been suggested that there are links between ridge-crest subduction, uplift of the Antarctic Peninsula, and the onset of glaciation (see Elliot, 1997). These are unproven but may be tested by drilling. The central plateau's resemblance to a peneplain is marked, but constraints on the time of uplift are sparse. Uplift may have been diachronous along the margin, resulting from ridge-crest subduction, but an age as old as Late Cretaceous is not ruled out. It is suggested also that the creation of a 2-km-high ridge of mountains would have affected precipitation and local climate sufficiently to have caused the development of an ice sheet. In a region of high precipitation, uplift should be followed quickly by erosion, so there is the opportunity to examine the provenance of the terrigenous component of the drilled sediments for signs of progressive unroofing of a newly elevated Antarctic Peninsula.

\section{Antarctic Peninsula Glacial History}

It is useful to summarize what is known of Antarctic Peninsula glacial history, from work onshore and conjectured from (mainly seismic) work offshore. Onshore evidence has been published (see Birkenmajer, 1992; Elliot, 1997) of early or middle Eocene as well as early and late Oligocene glaciations on the South Shetland Islands (northern Antarctic Peninsula). These conflict with other evidence of regional climate; for example, from ODP Leg 113 (Mohr, 1990; Kennett and Barker, 1990). Late Miocene glacial deposits are found on Seymour Island (Smellie et al., 1988). Sloan et al. (1995) suggested a late Miocene age for sediments on the Weddell Sea margin, identified as glacial and glaciomarine in seismic profiles; Bart and Anderson (1995) suggested a middle Miocene onset on the Pacific margin on similar grounds. It is generally considered that the Antarctic Peninsula can provide a highresolution record of glaciation back to perhaps $10 \mathrm{Ma}$. To go back farther could involve entanglement with the tectonics of ridge-crest collision (see above), making a problem out of an asset. However, because of the Antarctic Peninsula's more northerly position, its glacial history is shorter than East Antarctica's; the record before 10 Ma may be largely nonglacial, or may reveal a stage of valley glaciation lacking regular icesheet extension to the continental shelf edge.

\section{ANTARCTIC PENINSULA MARINE GLACIAL SEDIMENTATION}

\section{Continental Shelf}

Glacial sedimentation is preserved on the outer continental shelf and slope as tills and diamict within the prograded wedge, on the upper 
continental rise within hemipelagic sediment drifts, and on the abyssal plain as turbidite sands. The aims of Leg 178 were to sample the first two of these environments as well as a pocket of postglacial sediment on the inner shelf.

The inner continental shelf is a region of rugged topography, underlain by hard rock. Some of the islands exceed $2000 \mathrm{~m}$ in height. Water depths in the channels and fjords exceed $1000 \mathrm{~m}$ in places, and the rugged submarine topography results from glacial overdeepening of lines of weakness, structurally controlled. Radiocarbon ages suggest that the inner shelf was uncovered by 5-6 ka (Clapperton and Sugden, 1982; Harden et al., 1992) or earlier. Sidescan sonar records from the inner shelf show mostly bare, jointed rock, with thin sediment ponds confined to local troughs (Pudsey et al., 1994). In Palmer Deep, the sediment cover is significantly thicker and may well be older than $6 \mathrm{ka}$ (Leventer et al., 1996; Rebesco et al., 1998). Rapidly deposited modern proglacial sediment occupies the floor of some inshore fjords (Domack and McClennen, 1996).

The middle and outer shelves, separated by the MSH, are much smoother than the inner shelf but exceed $600 \mathrm{~m}$ water depth in places (Fig. F5); some sidescan sonar records from the middle shelf show an erosional topography reflecting preglacial sedimentary geology. Sidescan sonar and $3.5-\mathrm{kHz}$ profiles on the middle and outer shelf west of Anvers Island (Pudsey et al., 1994) show two fabrics. An older set of striations is interpreted as glacial flutes, lying along glacial troughs emerging from the main deep exits from the inner shelf, which were the loci of ice streams. On these, in the shallower outer shelf area, is superimposed a later set of more randomly oriented furrows, caused by icebergs moving under the influence of tides and shelf currents following the retreat of the ice-shelf front. The outer shelf is generally too deep (300$500 \mathrm{~m}$ ) for any icebergs now produced in this region to ground there. Overlying these features, and concealing them inshore, is a thin $(<5 \mathrm{~m}$ offshore and $<20 \mathrm{~m}$ inshore) layer of pelagic diatomaceous mud above a proximal glaciomarine diamict. Interglacial deposition appears greater inshore than at the shelf edge, presumably as a result of current maxima around the shelf edge, an inshore source of suspended terrigenous fines, and perhaps more stable water mass stratification inshore, which would encourage diatom blooms. Interglacial deposition on the upper continental slope is probably slow for similar reasons. Cores from the middle and outer shelf (Pope and Anderson, 1992; Pudsey et al., 1994) give about 11-ka radiocarbon ages for horizons close to the base of the diatomaceous facies, dating the onset of open marine conditions. Retreat across the middle and outer shelf appears to have been rapid.

The middle and outer shelf of the Antarctic Peninsula is typical of Antarctic continental shelves, in deepening inshore from a shallow shelf edge and in having a thin, unconsolidated glaciomarine surface sediment layer overlying a diamict. In other places, too, similar radiocarbon ages have been determined (e.g., Prydz Bay [Domack et al., 1991a]). These features all reflect the retreat since glacial maximum of an ice sheet grounded almost everywhere to the continental shelf edge.

In general terms, the ice sheet covering the continental shelf during glacial periods is assumed to have been subject to the same range of constraints as modern ice sheets. Ice-stream flow was governed by the surface slope and the basal boundary condition. Water and thus, in most cases, low-strength dilated till, were available to enable fast flow. We assume that the ice sheet was generally thick and slow moving on the inner shelf, where basal sediment supply would have been low, 
requiring erosion of hard rock. Much of the seabed of the middle shelf is softer and more erodable, particularly during early advance when interglacial biogenic muds are available, but ultimately the till supply must come from the inner shelf or from middle-shelf bedrock erosion. In contrast, the outer shelf is essentially depositional and floored by thick tills. We see the outer shelf as the site of low-profile, fast-flowing ice streams because of the abundant till supply. These ice streams transported till to the continental shelf edge, building the progradational lobes. During the present interglacial, an ice-covered environment resembling the glacial-age outer shelf is difficult to find; perhaps, however, the "lightly grounded" area of the Ross Sea described by Shabtaie and Bentley (1987) is analogous.

The Antarctic Peninsula continental shelf has been the object of intense study, using a dense network of single-channel and multichannel seismic reflection profiles largely within the ANTOSTRAT framework. (A composite track chart is depicted in Fig. F10, and details of the origins of data at or close to sites are given in the "Explanatory Notes" chapter. See also "Appendix," p. 24, and Fig. AF1, p. 59, both in the "Leg 178 Summary" chapter) The data show that the outer shelf is underlain by a thick prograded wedge of sediments, containing deeper reflectors that possess the same characteristics as the present seafloor (inward slope, high topset reflectivity, and high acoustic velocity). These characteristics, together with a steep continental paleoslope and a gradually prograding paleoshelf break that nowhere shows signs of migration of the effective level of erosion from the present ice-stream base to a nonglacial (wave base) level, imply a glacial origin (Larter and Barker, 1989). The glacial-age sediments have been described and interpreted in many papers (e.g., Larter and Barker, 1989, 1991b; Anderson et al., 1990, 1991; Larter and Cunningham, 1993; Barker, 1995a; Bart and Anderson, 1995; Vanneste and Larter, 1995; Larter et al., 1997).

The prograded sediments along the Antarctic Peninsula outer shelf are focused into four depositional lobes (Figs. F8, F11), where both progradation of the paleoshelf edge and depression of the outer paleoshelf are maximal. Four shelf sediment sequence groups have been identified (Larter and Barker, 1989, 1991b; Larter and Cunningham, 1993; Larter et al., 1997; Fig. F12). S1 and S2 are clearly glacial. The MCS data do not resolve individual till units, so subdivision at the level of a single glacial cycle is impossible. Also, subsequent glacial erosion tends to remove topset beds, leading to the apparent merger of deposits corresponding to a single cycle into a larger sequence. Nevertheless, several sequences were identified within both S1 and S2. At the S2/S1 boundary, erosion has removed S2 topsets and truncated foresets. This characteristic relationship between S1 and S2 can be clearly seen along the entire margin to at least $105^{\circ} \mathrm{W}$ in the Amundsen Sea (Nitsche et al., 1997), even though S1 is not always continuous between depositional lobes. Progradation in S1 and S2 is greatest within the lobes, but at least some progradation of these two sequence groups is seen everywhere along the margin. Isostatic response to loading by S1 and S2 topsets and foresets appears fairly local along the Antarctic Peninsula margin, as would be expected for relatively young oceanic lithosphere; the S3/S2 boundary, therefore, lies far deeper beneath the lobes than in an interlobe area, where it is more accessible to drilling.

Deep-tow boomer data collected on the outer shelf off Anvers Island (Vanneste and Larter, 1995) provide more detail of the uppermost units of S1, both along the axis of a lobe and in an interlobe area (between L1 and L2). Till units appear to be 10 to $50 \mathrm{~m}$ thick and to vary in thick-
F10. Composite track chart of multichannel and single-channel seismic data used in selecting drill sites, p. 38.

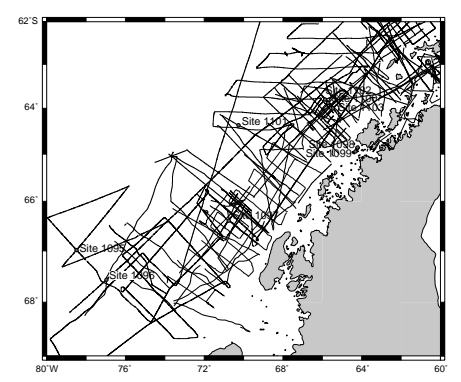

F11. Schematic figure of tectonic and glacial elements of the Antarctic Peninsula margin and Leg 178 sites, p. 39.

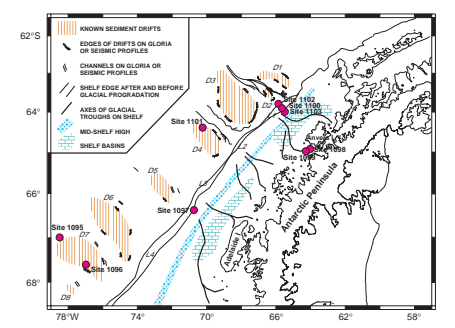

F12. MCS profile AMG 845-08, showing glacial Sequence Groups S1 and S2 overlying Sequence S3, and S4, p. 40.

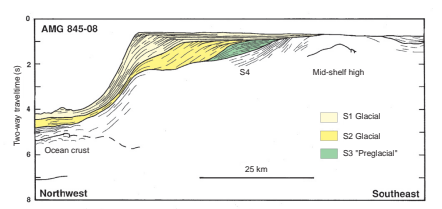


ness laterally. They are bounded by reflectors much smoother than the present seabed, which is disturbed by iceberg plow marks 5-10 $\mathrm{m}$ deep and as much as $50 \mathrm{~m}$ across. It seems likely that in many areas the present rough seabed topography will be smoothed or planed off during the next ice advance. The deep-tow boomer data identify an area where the youngest till body appears not to have reached the continental shelf edge (Fig. F13). This body has a sloping front, dipping seaward at $>2^{\circ}$ and showing faint internal reflectors that dip similarly. Vanneste and Larter (1995) suggest that this slope, at least $40 \mathrm{~m}$ high and $1 \mathrm{~km}$ long (its upper extent is confused by iceberg plowing), might be the normal prograding foreset slope of the till, a glacial continental shelf environment where the products of gravitational instability might develop within a till, close to the grounding line.

The continental slope is very steep, both on and between the lobes, reaching $17^{\circ}$ in places. Deep-tow boomer profiles of the upper slope (Vanneste and Larter, 1995) show no penetration but are able to help define slope morphology. They show an uppermost region full of smallscale headwall scarps and slumped blocks, suggesting slope failure. Lower down are seen small gullies, 40-80 m deep and 400-1000 m apart. These do not appear to merge or enlarge downslope, and seismic data suggest that the lower slope is smoother than the upper. We suggest that small till-laden debris flows originate in the failure of the uppermost slope, erode the slope gullies, then continue as turbidity currents onto the continental rise (see below), depositing coarse debris on the lower slope. Their small scale is evidenced by the scale of slumping and gullying, and their likely energetic nature is suggested by the steep slope and massive initial load. We observe the slope profile as it is now, some 10-20 k.y. into an interglacial, when this margin is effectively sediment-starved. We assume, however, following the seismic evidence, that there is net progradation of the slope during glacials, when the upper slope is being loaded. Importantly, there is no evidence of largescale slope failure within the prograded wedge along this margin.

Sequence S3 underlies S2, conformably in most places, and (mostly unconformably) overlies S4. S4 is considered precollision (see "Geology and Tectonics," p. 7), undeformed sediment deposited on the outer slope of a subducting margin, overlying an accretionary prism. Its truncation at the S4/S3 boundary is considered to have been caused by postcollision (mostly or entirely preglacial) uplift of the MSH and erosional truncation at wave base. In the appropriate margin segment, the S4/S3 boundary has been traced to the level at DSDP Site 325 associated with the loss of terrigenous deposition on the continental rise. The boundary is in fact diachronous along the margin, following collision.

Sequence 3 has been described as "preglacial." Its nature was unknown before drilling, but it lacks the clear progradational form of S1 and S2 as well as their focusing into depositional lobes. S3 resembles the Type IIA geometry attributed by Cooper et al. (1991) to "early glacial to nonglacial processes on normal water-depth shelves" and often seen beneath obviously glacial sequences. It appears to be of fairly uniform thickness along the margin, continuing to at least $105^{\circ} \mathrm{W}$ (Nitsche et al., 1997), and in most sections has a partly conformable boundary with the overlying S2. Given the present effective glacial erosion level, several hundred meters below wave base, it seemed from this conformity that either S3 was completely preglacial or an early glaciation stage. If S3 was preglacial, the depositional environment we were seeing was on a continental slope, deeper than the glacial erosion level. If S3 was glacial and its different geometry is a reflection of an earlier stage of
F13. Deep-tow boomer profile of part of the outer continental shelf off Anvers Island, p. 41.

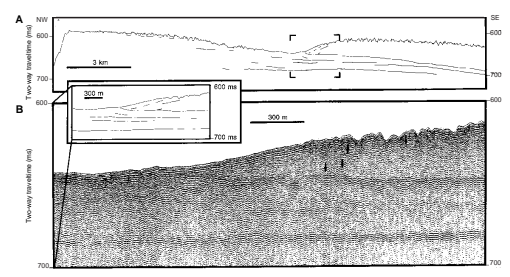


glaciation that does not involve marginal progradation or the creation of a sharp paleoshelf break, then we were seeing a glacial shelf environment.

\section{Continental Rise Drifts}

As already described, unsorted terrigenous sediment is supplied to the uppermost continental slope-abundantly along a broad front (mainly but not entirely from within progradational lobes) during glacial parts of the climate cycle but hardly at all during interglacials. The slope is extremely steep (up to $17^{\circ}$ in places) and has steepened with progradation. The slope shows no sign of large-scale slumping, but a part of the upper-slope glacial sediment is transported to the lower slope and rise by debris flow and turbidity current. Deep-tow boomer data from the upper slope, pointing to small-scale instabilities, have already been described (Vanneste and Larter, 1995).

Parts of the upper continental rise have been mapped by GLORIA sidescan survey (Tomlinson et al., 1992), seismic and $3.5-\mathrm{kHz}$ profiles (Rebesco et al., 1996, 1997), and short piston cores (Camerlenghi et al., 1997b; Pudsey and Camerlenghi, 1998). The GLORIA survey of the northeastern part of the rise shows a dendritic channel network at the base of the slope, feeding a small number of substantial channels that continue northwest, beyond GLORIA coverage. By means of this network, each main channel "drains" a section of the slope. The main channels appear to have a longer life span than a single glacial cycle, but some of the small feeder channels may not have. The series of upper-slope gullies may not connect with the channel network on the upper rise. There is no a priori evidence of the balance of turbidity current creation on the slope between glacials (when the uppermost slope is being loaded) and interglacials (when it is not), but the preservation of a glacial-interglacial cyclicity on the rise would suggest that the mean residence time of unstable sediments on the upper slope is short.

The major component of sedimentation on the upper rise is a series of mounds interpreted as hemipelagic drifts (Rebesco et al. 1994, 1996; McGinnis and Hayes, 1994, 1995; Camerlenghi et al., 1997b). Eight drifts, labeled D1-D8, are marked schematically on Figure F11 and appear also on Figure F5. The two largest (D6 and D7) are seen on MCS profile IT92-109, southwest of the Tula FZ and 100-170 km from the base of the continental slope (Fig. F14). These are elongated perpendicular to the margin, are $50 \mathrm{~km}$ across, and rise almost $1 \mathrm{~km}$ above their surroundings. The maximum sediment thickness beneath the crest of D6 may reach $3 \mathrm{~km}$. D6 and D7 appear as subdued gravity highs on the map of satellite-derived gravity (Fig. F8).

The drifts are asymmetric in section (parallel to the margin), which we believe reflects the influence of a slow southwest boundary current (above). We speculate that the drift sediments are derived from turbidity currents flowing from the continental slope along the channels between the drifts, by downcurrent transport of suspended fines (Fig. F3). D3 and part of D4 lie within the GLORIA coverage (Fig. F15), so that their relationship to the channel pattern is clear: D4 lies downcurrent of Channel IV; D3, between II and III. D3 is low and thin and may be accessible to turbidite overbank deposition. The smaller Drift D2 is confined between Channels I and II and appears on MCS profile AMG 845-04 (Larter and Cunningham, 1993). Beyond the GLORIA coverage, the relationship of drifts to slope is more conjectural. The great majority, however, appear on MCS profiles to be similarly isolated from direct
F14. MCS profile IT92-109

through Drift 7 with Site 1096 marked, p. 42.

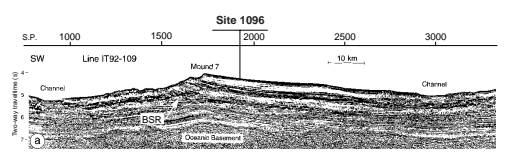

F15. GLORIA survey of northeastern Drifts D1 through D4 and intervening Channels I through IV, p. 43 .

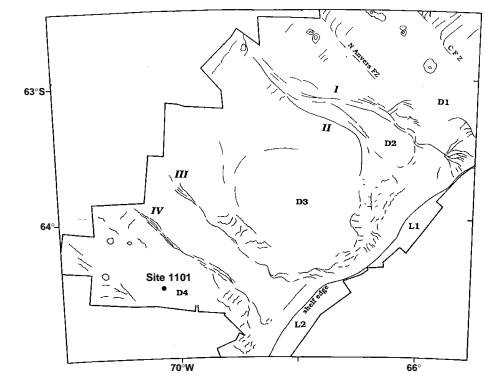


turbidite deposition and maintained by pelagic/hemipelagic deposition alone.

There is some uncertainty about the relative importance in a particular drift of sediment from the "local" margin channel system and from more distal sources. There is a close correspondence between the seismic sections within adjacent drifts (see Rebesco et al., 1996), which may be attributed to either a common distal source or a shared continental glacial climatic history (or both). The drifts become larger to the southwest, which could reflect either a growing distal contribution or growth in the proximal glacial source (as the Antarctic Peninsula becomes broader).

Six seismic sequences have been recognized within the two southwesterly drifts (D6 and D7 [Fig. F8]), which lie on ocean floor aged 35$40 \mathrm{Ma}$, within the 30-Ma collision zone. Sequence M6 drapes and fills basement topography and thickens from $0.5 \mathrm{~s}$ two-way traveltime to $1 \mathrm{~s}$ at the base of slope. The upper boundary may be the "uplift unconformity" at that collision segment of the margin. M6 just overlies 25-m.y.old basement in the next youngest collision segment to the northeast. Reflectors within Sequence M5 onlap the M6/M5 boundary and appear to have been planar and horizontal on deposition, suggesting a turbidite origin. Sequence M4 is of variable thickness and shows the earliest signs of the mounding that characterizes the drifts (though the early asymmetry appears opposite to that of the present day). The upper parts of both M5 and M4 show erosion in places near the base of slope.

Sequence M3 shows the main phase of drift growth (Rebesco et al., 1997). Reflectors in its lower part downlap onto the M4/M3 boundary, suggesting very little deposition away from the drifts, but deposition in its upper part was more even. Correlation with DSDP Site 325 suggests Sequence M3 is younger than $8 \mathrm{Ma}$. Sequences M2 and M1 show even deposition, except on the steep southwest scarp slopes: there are minor differences between the two sequences in the strengths of concordant reflectors. GLORIA data suggest that the scarp slopes are dissected by gullies.

Three of the drifts (D5-D7) have been described by McGinnis and Hayes $(1994,1995)$ on the basis of a different set of MCS profiles. They conceive of an originally more continuous, less dissected upper rise than is envisaged here, and yet a more dissected modern margin; they place great emphasis on submarine canyon cutting as a sign of and as a mechanism for its later dissection. McGinnis and Hayes invoke overbank deposition (instead of nepheloid transport) to form the drifts, and they see contour current erosion within the drifts and along the modern margin where we do not. We see the present topography as less extreme, and (on the basis of GLORIA evidence [Fig. F15]) we invoke dissection by small-scale turbidity currents to produce and maintain it. However, part of the disagreement concerns the earlier history of the drifts, which will not be accessible to the planned drilling. The remainder, although of great sedimentological interest, does not affect the value of the drifts as a high-resolution record of glacial history.

The February 1995 site-survey cruise aboard OGS-Explora recovered nine short gravity cores along strike and dip transects of Drift 7 (Camerlenghi et al., 1997b). Alternations of brown bioturbated diatom- and foraminifer-bearing mud with gray laminated barren mud extending across the entire gentle northeast slope of the drift are interpreted as having been produced during glacial cycles. The diatoms indicate a late Quaternary (Thalassiosira lentiginosa zone) age, and the $\mathrm{Ba} / \mathrm{Al}$ ratio (a proxy for paleoproductivity [Shimmield et al., 1993]) peaks at the core 
top (= Stage 1) and in a second foraminifer-bearing brown unit downcore assumed to be Stage 5e (Pudsey and Camerlenghi, 1998). This preliminary time scale gives sedimentation rates from 3 to $6 \mathrm{~cm} / \mathrm{k} . \mathrm{y}$.

The brown bioturbated mud occurs at each core top and in one or more units downcore. It is fine-grained with $0 \%-10 \%$ sand, $20 \%-30 \%$ silt, and $65 \%-80 \%$ clay. The sand fraction includes unsorted terrigenous grains of ice-rafted origin, with calcareous foraminifers and lesscommon radiolarians and volcanic glass shards. At the core tops there is a diverse radiolarian assemblage, and in the inferred Stage 5 sediment, planktonic and benthic foraminifers are abundant. Diatoms form as much as $30 \%$ of the fine fraction.

The gray laminated mud is barren of microfossils except for a trace of diatoms and is not bioturbated. Parallel lamination occurs extensively, with some wavy lamination in the upper parts of the cores, and the mud is very fine grained ( $<1 \%$ sand, $20 \%-30 \%$ silt, and $70 \%-80 \%$ clay). Both sediment types show remarkable lateral continuity across the drift. Magnetic susceptibility profiles and visible features in the cores permit the identification of 25 datum levels in the top few meters, which can be traced over distances of as much as $100 \mathrm{~km}$ across the drift.

The dip- and strike-section continuity across the drift shows that the lateral continuity of seismic and $3.5-\mathrm{kHz}$ reflection profiles extends to very high resolution, at least within a single drift. It also appears to verify that terrigenous sediment from the continental slope is supplied in numerous small-scale turbidity currents. The fine grain size supports the idea of slow bottom currents. Similarly, the glacial-interglacial lithologic variation supports the view that instability on the upper slope follows quickly after load, so that the residence time of unstable sediments on the slope is short. This is an important characteristic of the slope-rise transport system because it promises a high-resolution record of glacial-interglacial variation. The biogenic component of interglacial sediments is diverse, magnetic susceptibilities correlate precisely between cores, and remanence appears stable.

These cores apart, there are very few known sediment cores from the upper continental rise. $3.5-\mathrm{kHz}$ profiles show $50-100 \mathrm{~m}$ penetration across the drifts, usually a good indicator of fine grain size. British Antarctic Survey Cores PC054 and 055 from close to the margin, in essentially a proximal channel overbank area (also showing good $3.5-\mathrm{kHz}$ penetration) of Drift D3, have a thin biogenic hemipelagic mud overlying laminated silty and clayey mud with silt laminae. The Eltanin cores from the continental rise (Goodell, 1964) are described as silty clays and clayey silts with varying numbers of silt and sand laminae. Diatomaceous clay is described from the top of some, and some cores contain foraminiferal layers. It is impossible to tell which, if any, of the layers are turbidites. Clear turbidite sands are absent from the descriptions; we would expect turbidite sands to flow on past the drifts and to settle on the Bellingshausen abyssal plain to the north.

The importance of the drifts is that they provide a continuous hemipelagic sedimentary section intimately related to the glacial history of the adjacent continent. Sedimentation is likely to have been more continuous than on shelf or slope and also rapid (perhaps exceeding 10 $\mathrm{cm} / \mathrm{k} . \mathrm{y}$.). Magneto- and biostratigraphic control seem assured, and there is significant glacial-interglacial lithologic variation, which is continuous at high resolution across the drift. The drifts seem likely to contain a high-resolution, drillable record of Antarctic glacial history that can be correlated to the more direct record of the shelf and slope. 


\section{PALMER DEEP (SITES 1098 AND 1099) HOLOCENE RECORD}

The overdeepened Antarctic inner continental shelves, with water depths often exceeding $1000 \mathrm{~m}$, create deep repositories that efficiently trap the products of near-shore productivity during interglacials (Domack et al., 1991b; Leventer et al., 1996). In contrast to outwardsloping, low- to middle-latitude continental shelves, the sedimentary record is preserved because biogenic particles are not easily removed. Periodically, the advance of a grounded ice sheet across the continental shelf removes by basal erosion all or most soft sediments deposited during the previous interglacial. The record in the inner-shelf basins, therefore, is believed to be no older than the LGM. Palmer Deep, south of Anvers Island, is one such basin.

The following sites aimed at ultrahigh-resolution late Quaternary sedimentary records of paleoproductivity have been successfully drilled by the Ocean Drilling Program in areas where local geological conditions (tectonically overdeepened marginal basins with suboxic or anoxic conditions, or northern mid-latitude anoxic fjords) have allowed their preservation:

1. The Santa Barbara Basin (ODP Leg 146, Site 893), a semi-enclosed basin of the Southern California continental margin in $600 \mathrm{~m}$ water depth, recording annual laminations during periods of suboxic oceanographic conditions in the late Pleistocene;

2. The Cariaco Basin (Leg 165, Site 1002), an anoxic basin in $900 \mathrm{~m}$ water depth on the margin of Venezuela that yields a record of latest $(200,000 \mathrm{yr})$ Quaternary tropical climate variability on time scales of tens to hundreds of years; and

3. Saanich Inlet (Leg 169S, Sites 1033 and 1034), an anoxic fjord with water depth between 140 and $200 \mathrm{~m}$, off southern Vancouver Island, Canada, recording in varved sediments the seasonal variation of sedimentation throughout the Holocene.

Palmer Deep is the first such site in the Southern Hemisphere high latitudes, in an area directly influenced by ice-cover fluctuations and widely recognized as highly sensitive to climatic change, at least in historical time (Doake and Vaughan, 1991; Fraser et al., 1992; Jacobs and Comiso, 1993; Ridley, 1993; Skvarca, 1993; Smith, 1994; Domack et al., 1995). Palmer Deep, just south of Anvers Island (Fig. F5), is probably the best known of the overdeepened inner-shelf basins on the Antarctic margin: the site is a rimmed seafloor depression with maximum water depth of $1400 \mathrm{~m}$, in which lie three flat-floored sub-basins (Kirby et al., in press). It has been intensively investigated with high-resolution deep-tow and seismic reflection techniques (Kirby et al., in press; Rebesco et al., 1998) and with piston coring (Kirby et al., in press; Leventer et al., 1996). Oceanographic measurements and sediment trap deployments are under way (E. Domack, pers. comm., 1997).

Sediments in Palmer Deep are alternations of laminated siliceous ooze and hemipelagic mud, with minor locally derived turbidites. Analyses of piston cores have outlined downcore variations of magnetic susceptibility, grain size, organic carbon, bulk density, and diatom and foraminiferal assemblages and abundances. These demonstrate shortterm $(\sim 200 \mathrm{yr})$ and longer term $(\sim 2500 \mathrm{yr})$ cycles, most probably related to global climatic fluctuations (Leventer et al., 1996; Fig. F16), at least
F16. Magnetic susceptibility from marine sediment core from Palmer Deep, p. 44.

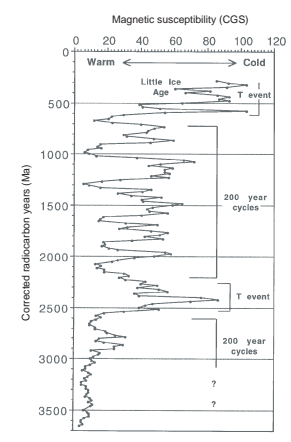


down to $3700 \mathrm{yr}$, according to radiocarbon dating. The 200-yr cycles are thought to reflect alternations of periods of high productivity, driven by higher atmospheric and seawater temperature and greater flux of meltwater from the ice fronts; and those of lower productivity, resulting from colder temperatures, more storms, and better mixing in the water column. These 200-yr cycles, possibly driven by variations in solar activity, have been identified in other terrestrial records such as tree rings (Wigley, 1988; Scuderi, 1993), lake sediments (Anderson, 1992), and ice-core records (Raisbeck et al., 1990). They appear to have global significance.

For the Antarctic, the possibility of correlating the ice and the marine sediment records at a decadal and centennial scale is important because it would provide a link between paleo-atmospheric conditions, directly recorded in the ice cores; and paleoceanographic conditions, directly recorded in the sediment cores. Both will contribute to the reconstruction of a global paleoclimate record since the LGM.

The strategy of drilling in Palmer Deep was developed in two stages. First, from the deep-tow-boomer and piston-core records, it was known that Basin I, the smallest and shallowest of the three Palmer Deep subbasins, contained $40-50 \mathrm{~m}$ of sediment, possibly turbidite-free. From downward extrapolation of the sedimentation rate $(0.39 \mathrm{~cm} / \mathrm{yr})$ obtained by radiocarbon dating of the upper $10 \mathrm{~m}$, this section might extend the sedimentary record back to about 13ka at the basin base. Basins II and III, the deeper and larger basins (1400 m water depth), were thought to contain a similar sediment thickness but to include a higher proportion of turbidites. Sites in these basins were proposed as alternates to Basin I in case of adverse ice conditions.

Second, an air gun survey of the area (February 1997), requested by the ODP Site-Survey Panel to improve seismic cover around the sites, revealed that Basins II and III contained a greater sediment thickness, reaching about $270 \mathrm{~m}$ in the center of Basin III. Estimates of the age of the deeper sediments in Basin III, aided by seismic stratigraphic correlation, suggested that, despite the higher sedimentation rate (caused by turbidites), the lower sediments in Basin III could be older than in Basin I, thus possibly extending the record to before the LGM. An addendum to the original proposal for drilling Basin I was then written (August 1997) to propose Basin III as an additional target, although the higher priority was retained for Basin I drilling.

Drilling in Palmer Deep as a site of opportunity has been supported by the newly formed ANTIME in the Antarctic program, which aims to reconstruct the glacial cycle of Antarctic history as part of the SCAR contribution to the IMAGES, part of the IGBP. The drilling also fits the objectives of the (mainly U.S.) West Antarctic Ice Sheet program and is located in the only marine area of the Long-Term Ecological Research program.

\section{OTHER CONSIDERATIONS}

\section{Eltanin Impact}

A report (Gersonde et al., 1997) of recent shallow piston coring around the estimated site of a late Pliocene asteroid impact identified originally from early Eltanin piston cores (Kyte et al., 1981, 1988; Kyte and Brownlee, 1985; Margolis et al., 1991) has renewed interest in an event that might be detectable at Leg 178 sites on the continental rise 
drifts. The event has been dated at $2.15 \mathrm{Ma}$, close to the Reunion geomagnetic polarity event (C2r.1n) and in oxygen isotope Stage 82 (Gersonde et al., 1997). It is proposed that an asteroid 1 to $4 \mathrm{~km}$ in diameter struck an area close to $57.8^{\circ} \mathrm{S}, 90.8^{\circ} \mathrm{W}$, ejecting large volumes of seafloor sediment and also providing an impact-generated airborne cloud of melted asteroidal debris. The debris has a distinctive geochemical anomaly, unmixed with ocean-floor material, and the ejected sediment is reported to be early Eocene to Pliocene calcareous and nannofossil ooze with minor diatoms and radiolarians. In addition, an impact of this magnitude is considered likely to have generated a "megatsunami" of $20-40 \mathrm{~m}$ amplitude in deep water, increasing manyfold in the shoaler waters of a continental margin (Gersonde et al., 1997). There have been many recorded occurrences of reworked continental shelf material transported inland by tsunamis and of a "homogenite" on the floor of the enclosed basin of the eastern Mediterranean with a wider grain-size distribution and an origin at least partly in sediments from the surrounding continental shelf and slope (Cita et al., 1996). Suspension of fine-grained sediment in deep water is not ruled out.

Irrespective of the amplitude and depth penetration of such a phenomenon, we would anticipate a significant effect at the Antarctic Peninsula margin, about $1500 \mathrm{~km}$ away, and probably also toward the crest of the drifts, some $1300 \mathrm{~km}$ away, where the water depth is less than three-quarters that of the direct path of the megatsunami from the impact site. The effect at the Antarctic margin would depend crucially on the stage of glaciation: well into an interglacial, with the ice-grounding line far inshore and the continental slope in a relatively stable "starved" situation, the effect might have been minimal. During a glacial period, however, with an ice sheet grounded to the continental shelf edge and an upper slope loaded with potentially unstable glacially transported sediment, the effect could have been far greater, generating unusually large debris flows and turbidity currents everywhere along the margin. Subsequent events on the shelf would most probably have erased the shelf record of such an event, but the resulting effect on the continental rise drifts should have been preserved. We might therefore be looking for a geochemical anomaly, involving air-fall asteroid debris (spherules and a derived noble metals anomaly) together with early Eocene to Pliocene biogenic material, also airborne, above a possible but not inevitable megaturbidite or other anomalous sedimentary expression of a large-scale tsunami.

\section{Bottom-Simulating Reflectors}

Sediments within the drifts on the continental rise exhibit a strong bottom-simulating reflector (BSR) at 550-650 ms depth. It is clear beneath the scarp faces (e.g., Fig. F14: shotpoints 1400-1700 and 51005400) but less so beneath the gentler flanks where bedding is parallel to the seafloor. It caused some concern before Pollution Prevention and Safety Panel review as a potential gas hydrate BSR, as did the possibility of stratigraphic traps on the continental shelf. We had aimed to drill through or to the BSR at the prime rise site.

We did not expect thermogenic hydrocarbons at the sites, either on the rise or on the shelf. In general terms, the offshore Antarctic Peninsula has seen considerable activity from expeditions, national scientific base relief, and marine scientific surveys over the past $80 \mathrm{yr}$-and from whalers and sealers for $80 \mathrm{yr}$ before that. No hydrocarbon shows have ever been reported, although there have been indications of methane 
in Bransfield Strait to the northeast. This last is a region of high biogenic productivity as well as active extension leading to high geothermal gradients and is not an analogue for the regions of the proposed sites.

The key factors governing hydrocarbon potential of the shelf are probably

1. The absence of terrigenous vegetation on the Antarctic Peninsula margin during glacial times;

2. The accumulation of immature clastics in an accretionary wedge before ridge-crest subduction; and

3. The onset of fully glacial conditions with erosion at the ice-sheet base, and deposition of (unsorted) diamictons on shelf and slope, at some time between 10 and $6 \mathrm{Ma}$.

Also, the subducted ridge crest was a heat source but caused uplift (focused on the mid-shelf high) and consequent subaerial erosion of the existing sedimentary succession (S4 in Fig. F12). This happened shortly (14 m.y.) after collision. Collision ages are $11 \mathrm{Ma}$ for the shelf transect (Sites 1100, 1102, and 1103) and 16.5 Ma for the shelf interlobe site (1097). Thus, although there are probably stratigraphic traps now at the top of S4 close to the mid-shelf high, these were outcropping at the time of high heat flow following ridge-crest collision.

Only two BSRs recognized around Antarctica have been attributed to gas hydrates: one is on the landward slope of the South Shetland Trench (Lodolo et al., 1993). On the South Orkney microcontinent (Lonsdale, 1990), a BSR considered beforehand to be from the base of a gas hydrate was shown by ODP Leg 113 drilling to have resulted from silica diagenesis. South of the Polar Front, biogenic silica is abundant and widespread within pelagic and hemipelagic sediments, and diagenetic alteration of silica at depth is likely to be common.

It should be straightforward to distinguish between the two: the base of a gas hydrate is related to pressure and temperature-almost all known marine hydrate BSRs involve the simplest mixture, methane and seawater-and heat flow over the ocean floor is a known function of ocean-floor age and sedimentation rate. Thus, a preliminary estimate of the depth of a methane hydrate BSR can be made. Also, with a methane hydrate, the bedding above the BSR commonly shows a lower range of acoustic impedance contrast than the bedding below. The acoustic impedance reduces downward, leading to a negative polarity reflector. In contrast, with a silica diagenetic reflector, the range of impedance contrast is reduced below the reflector, impedance increases downward, and the reflector has positive polarity. Silica diagenesis is in general terms the product of a time-temperature integration, so depths cannot be predicted precisely (see Lonsdale, 1990). Although there are occasionally strange chemical effects, possibly biologically mediated, depths of silica diagenesis BRSs are generally greater than would be predicted for a methane hydrate BSR in an area of known age.

We believe the BSR that is widely seen over the drifts is caused by silica diagenesis. We have considered both origins for the reflector and strongly favor diagenesis, for the following reasons:

1. Reflector polarity is difficult to establish because the reflector is diffuse where it crosses bedding and is hard to distinguish where it is parallel to bedding. We would say it is positive, which favors a diagenetic origin. The reflector is also in places diffuse, which 
might favor a diagenetic over a pressure/temperature-sensitive phase boundary origin.

2. Impedance contrast is sometimes difficult to see on the continental rise, but for most occurrences, impedance contrasts above are clearly greater (supporting a diagenetic origin).

3. Depth of a gas hydrate BSR provides a measure of heat flow. Over ocean floor of known age, heat flow is predictable. There is minor uncertainty in heat flow attaching to the history of sedimentation in a thickly sedimented section, but that too is calculable. The ocean floor beneath these rise sites is well dated and ranges in age between 42 and $35 \mathrm{Ma}, 20$ and $14 \mathrm{Ma}$ beneath the two drifts targeted (Sites 1095, 1096, and 1101). If these BSRs were gas hydrates, with the sediment thicknesses present, they should lie in the range of 300-500 ms depth at these sites. In fact, the BSR depths lie in the range of 550-700 ms.

4. Piston cores from the drifts show abundant biogenic silica (mostly diatoms) within interglacials, and there is every reason to believe it continues to depth. If so, a silica diagenetic reflector should occur within the drifts, and the measured depth would be reasonable.

Nevertheless, it was intended to measure heat flow in the upper part of Site 1096, where the BSR is well developed, to provide an early test of its likely origin there.

\section{SITES AND SITE-SPECIFIC OBJECTIVES}

Site locations are shown in Figures F5 and F11. Three sites (1095, 1096, and 1101) were occupied on sediment drifts on the continental rise, and four sites were on the outer continental shelf (1100, 1102, and 1103 on the "shelf transect" of a depositional lobe and 1097 in an interlobe area). Two short sites (1098 and 1099) were drilled inshore, at Palmer Deep. For a brief summary of drilling at these sites, see Table T1, p. 54, in the "Leg 178 Summary" chapter.

\section{Rise Sites 1095, 1096, and 1101}

Sites 1095 and 1096 (prospectus sites APRIS-02A and 01A) were located on Drift 7 and were intended to be complementary. The main site (1096), close to the crest of Drift 7, was intended to sample the expanded upper part of the sedimentary section within the drift. The lower part of the drift section was more accessible at Site 1095, in a more distal position on the northwest flank, where the upper section was known from seismic reflection profiles to be significantly thinner. The intention was to double sample the upper section at each site, using the advanced hydraulic piston corer (APC), then drill with the extended core barrel (XCB) to refusal or to target depths and log the deep holes. Together, these two sites were intended to cover the last 6 to 10 m.y., the likely extent of Antarctic Peninsula glacial history.

The drifts are assumed to be formed largely of the hemipelagic, bottom-current-transported fine fraction of the unstable component of glacially transported sediment deposited on the upper continental slope (Fig. F3). The nature and similarity of seismic reflection profiles across the drifts support this view. The nature and similarity of sediments from short piston cores also support the conclusion that the unstable 
component of upper-slope deposition has a short residence time compared to a glacial cycle. The sites should therefore contain a high-resolution record of ice-sheet grounding to the continental shelf edge. There should also be sufficient biogenic interbeds (mainly during interglacials when sea ice cover was less) for biostratigraphic control and a sufficient fine-grained terrigenous component to assure a stable magnetic remanence. However, the record will be indirect: it will be necessary to correlate events on the rise and on the shelf in order to interpret the rise-drift record in terms of the state of continental glaciation. An additional objective at the rise sites was to try to identify any effects of the Pliocene Eltanin impact. A tsunami-like disturbance of the seabed, especially if accompanied by air-fall redistribution of both asteroid fragments and Eocene-to-Pliocene biogenic sediments, could be detectable at an elevation $1 \mathrm{~km}$ above the surrounding ocean floor, as the crest of the drift would have been.

Site 1101 was an additional site, on Drift 4, that became possible because environmental limitations on drilling on the continental shelf made time available. It was drilled by APC and XCB to a little more than $200 \mathrm{~m}$ to resample the upper part of the section sampled at Sites 1095 and 1096. Certain features of those sites could have been heavily influenced by local events (e.g., the development of an additional channel system). We therefore thought it necessary to distinguish between local and regional developments before trying to correlate events on the rise and on the shelf in search of paleoclimate inference. Site 1101 lay on a different drift, some distance along the margin from Drift 7 and within GLORIA coverage. It was a new site, roughly halfway between existing alternate sites, chosen on the basis of results from Sites 1095 and 1096.

\section{Continental Shelf Sites 1097, 1100, 1102, and 1103}

Leg planning included four sites on a dip transect along the axis of Lobe 1, off Anvers Island (prospectus sites APSHE-01 through -04). There was also an additional site between Lobes 3 and 4 (APSHE-05) where the lower part of the section (Sequence S3) was less deeply buried and thus accessible to drilling. Because of time lost waiting for ship heave to drop below the specified 2-m limit, it was only possible to access the interlobe site (1097) and three shelf transect sites (1100, 1102, and 1103). The aim of shelf drilling was to date the major changes in the geometry of the glacial prograded wedge; these changes were assumed to mark major shifts in the development of the ice sheet. The main shelf transect lay along the line of Figure F12. It provided the opportunity to date the main changes in the geometry of the two known glacial sequence groups (S1 and S2) and to examine the S3/S2 boundary (which may or may not have coincided with the onset of Antarctic Peninsula glaciation). Sites were planned (1) at the shelf edge (APSHE-01) to sample slope foresets; (2) with two close together (APSHE-02 and 03) to sample the beginning and end of the process that eroded the topsets and truncated the foresets of S2; and (3) with one (APSHE-04) to sample the S3/S2 boundary, farther inshore. In fact, the ship visited the shelf edge (Site 1100) and the inner of the two S2/S1 sites (Site 1100), but to little effect because of ship heave. The inner end of the shelf transect at an alternate site (APSHE-10) was then drilled. At this location S2 is pinched out completely, and it is possible to drill through a thinner sequence of S1 topsets into the lower part of S3 (Site 1103). Earlier, it had been possible to drill the interlobe site (1097). 
Palmer Deep Sites 1098 and 1099

Sites 1098 and 1099 (prospectus sites APSHE-13 and 15) are located in Basins I and III of Palmer Deep, on the inner continental shelf directly south of Anvers Island (Leventer et al., 1996). Three linked basins contain an ultrahigh-resolution Holocene record of Antarctic Peninsula climate. Short piston cores from Basin I show a pronounced 200- to 300-yr periodicity in paleoproductivity that is also seen in some Antarctic Peninsula fjords. The expanded, presumed pelagic section may be compared with recently acquired records from low and intermediate latitudes (Santa Barbara Basin, Saanich Inlet, and Cariaco Basin) and ice-core records from Greenland and Antarctica to examine decadal and millennial variability on a global scale. This record may also provide opportunities to examine magnetic secular variation and, for the inshore environment, the time variability of the ${ }^{14} \mathrm{C}$ "reservoir effect," which is large but uncertain for waters south of the Polar Front. Site 1098 in Basin I, presumed to contain a much lower component of locally derived turbidites, is triple APC-cored to basement. Site 1099 in Basin III is a single APC core to more than twice the depth of 1098, in an effort to sample older sediments, to below a prominent high-amplitude reflector that was assumed to mark the beginning of the high-resolution biogenic section.

\section{WEATHER, ICE, AND DRILLING}

The Pacific margin of the Antarctic Peninsula is among the most accessible parts of the continent. Icebergs in this region are rare, and sea ice melts back southward through the season. Most of the northern sites should be accessible from the beginning of January to early May, and the southern sites from mid-January to late April. The sea ice distribution for the period from 1978 to 1987 derived from satellite information is published by Gloersen and Campbell (1992). The ice window for the leg was January to mid-April. The better weather is in January and February, and the weather begins to deteriorate in March, toward the equinox. In view of the operational danger from icebergs, an ice-picket boat (Polar Duke) was chartered for the leg and an ice observer employed. The ice-picket boat was able to detect and report iceberg movement beyond the range of drillship radar and was available to tow the drillship, or take drillship personnel on board, in an emergency.

Drilling on the rise sites involved APC and XCB (generally double or triple) coring. These sites are in fine-grained alternating biosiliceous and barren muds and mudstones. The prime ultrahigh-resolution site in Palmer Deep, assumed to be essentially a diatom ooze, was also sampled by triple APC. The other shelf sites posed problems, in that the unsorted diamictons were unsuitable for APC/XCB sampling. All such sites were therefore planned to be rotary-drilled from the seabed down. Recovery was expected to be reduced because of the expected lithology. The targets, however, essentially dating the main changes in geometry of deposition, were considered attainable with low recovery, with understanding of the depositional environment to be enhanced by downhole logging. 
REFERENCES

Adie, R.J., 1954. The petrology of Graham Land: I. The basement complex: early Palaeozoic plutonic and volcanic rocks. Falkland Islands Dependencies Surv. Sci. Rep., 11, London.

Adie, R.J., 1955. The petrology of Graham Land: II. The Andean granite-gabbro intrusive suite. Falkland Islands Dependencies Surv. Sci. Rep., 12, London.

Alley, R.B., Blankenship, D.D., Rooney, S.T., and Bentley, C.R., 1989. Sedimentation beneath ice shelves: the view from Ice Stream B. Mar. Geol., 85:101-120.

Anderson, J.B., Bartek, L.R., and Thomas, M.A., 1991. Seismic and sedimentologic record of glacial events on the Antarctic Peninsula shelf. In Thomson, M.R.A., Crame, J.A., and Thomson, J.W. (Eds.), Geological Evolution of Antarctica: Cambridge (Cambridge Univ. Press), 687-691.

Anderson, J.B., Pope, P.G., and Thomas, M.A., 1990. Evolution and hydrocarbon potential of the Antarctic Peninsula continental shelf. In St. John, B. (Ed.), Antarctica as an Exploration Frontier-Hydrocarbon Potential, Geology and Hazards. AAPG Stud. Geol., 31:1-12.

Anderson, R.Y., 1992. Possible connections between surface winds, solar activity, and the earth's magnetic field. Nature, 358:51-53.

Banfield, L.A., and Anderson, J.B., 1995. Seismic record of glacial events affecting the Pacific margin of the northwestern Antarctic Peninsula. In Cooper, A.K., Barker, P.F., and Brancolini, G. (Eds.), Geology and Seismic Stratigraphy of the Antarctic Margin. Antarct. Res. Ser., 68:123-140.

Barker, D.H.N., and Austin, J.A., Jr., 1994. Crustal diapirism in Bransfield Strait, West Antarctica: evidence for distributed extension in marginal basin formation. Geology, 22:657-660.

Barker, D.H.N, and Austin, J.A., Jr., 1998. Rift propagation, detachment faulting, and associated magmatism in Bransfield Strait, Antarctic Peninsula. J. Geophys. Res., 103:24017-24043.

Barker, P.F., 1982. The Cenozoic subduction history of the Pacific margin of the Antarctic Peninsula: ridge crest-trench interactions. J. Geol. Soc. London, 139:787-801.

Barker, P.F., 1992. The sedimentary record of Antarctic climate change. Philos. Trans. R. Soc. London B, 338:259-267.

Barker, P.F., 1995a. The proximal marine sediment record of Antarctic climate since the late Miocene. In Cooper, A.K., Barker, P.F., and Brancolini, G. (Eds.), Geology and Seismic Stratigraphy of the Antarctic Margin. Antarct. Res. Ser., 68:25-57.

Barker, P.F., 1995b. Tectonic framework of the east Scotia Sea. In Taylor, B. (Ed.), Backarc Basins: Tectonics and Magmatism: New York (Plenum), 281-314.

Barker, P.F., and Cooper, A.K., 1997. Geology and Seismic Stratigraphy of the Antarctic Margin (Pt. 2). Antarctic Res. Ser., 71.

Barker, P.F., and Dalziel, I.W.D., 1983. Progress in geodynamics in the Scotia Arc region. In Cabre, R. (Ed.), Geodynamics of the Eastern Pacific Region, Caribbean and Scotia Arcs, Am. Geophys. Union Geodyn. Ser., 9:137-170.

Barker, P.F., Dalziel, I.W.D., and Storey, B.C., 1991. Tectonic development of the Scotia Arc region. In Tingey, R.J. (Ed.), Geology of Antarctica: Oxford (Oxford Univ. Press), 215-248.

Barrett, P.J., 1996. Antarctic paleoenvironment through Cenozoic times-a review. Terra Antarct., 3:103-119.

Barron, J., Larsen, B., et al., 1989. Proc. ODP, Init. Repts., 119: College Station, TX (Ocean Drilling Program).

Bart, P.F., and Anderson, J.B., 1995. Seismic record of glacial events affecting the Pacific margin of the Northwestern Antarctic Peninsula. In Cooper, A.K., Barker, P.F., and Brancolini, G. (Eds.), Geology and Seismic Stratigraphy of the Antarctic Margin. Am. Geophys. Union, Antarct. Res. Ser., 68:75-96. 
Bartek, L.R., Vail, P.R., Anderson, J.B., Emmet, P.A., and Wu, S., 1991. Effect of Cenozoic ice sheet fluctuations in Antarctica on the stratigraphic signature of the Neogene. J. Geophys. Res., 96:6753-6778.

Birkenmajer, K., 1992. Evolution of the Bransfield basin and rift, West Antarctica. In Yoshida, Y., Kaminuma, K., and Shiraishi, K. (Eds.), Recent Progress in Antarctic Earth Science: Tokyo (Terra Publ.), 405-410.

Camerlenghi, A., Crise, A., Pudsey, C.J., Accerboni, E., Laterza, R., and Rebesco, M., 1997a. Ten-month observation of the bottom current regime across a sediment drift of the Pacific margin of the Antarctic Peninsula. Antarct. Sci., 9:426-433.

Camerlenghi, A., Rebesco, M., and Pudsey, C.J., 1997b. High resolution terrigenous sedimentary record of the sediment drifts on the Antarctic Peninsula Pacific margin. In Ricci, C.A. (Ed.), The Antarctic Region: Geological Evolution and Processes. Init. Results, SEDANO Progr., Terra Antarct., 705-710.

Cande, S.C., and Kent, D.V., 1995. Revised calibration of the geomagnetic polarity timescale for the Late Cretaceous and Cenozoic. J. Geophys. Res., 100:6093-6095.

Cita, M.B., Camerlenghi, A., and Rimoldi, B., 1996. Deep-sea tsunami deposits in the eastern Mediterranean: new evidence and depositional models. Sediment. Geol., 104:155-173.

Clapperton, C.M., and Sugden, D.E., 1982. Late Quaternary glacial history of George VI Sound area, West Antarctica. Quat. Res., 18:243-267.

Cooper, A.K., Barker, P.F., and Brancolini, G., 1995. Geology and Seismic Stratigraphy of the Antarctic Margin. Am. Geophys. Union, Antarct. Res. Ser., 68. (Atlas, CD-ROM).

Cooper, A.K., Barker, P.F., Webb, P.-N., and Brancolini, G., 1994. The Antarctic continental margin-the Cenozoic record of glaciation, paleoenvironments and sealevel change. Terra Antarct., 1/2:236-480.

Cooper, A.K., Barrett, P.J., Hinz, K., Traube, V., Leitchenkov, G., and Stagg, H.M.J., 1991. Cenozoic prograding sequences of the Antarctic continental margin: a record of glacio-eustatic and tectonic events. Mar. Geol., 102:175-213.

Cunningham, A.P., Vanneste, L.E., and ANTOSTRAT Antarctic Peninsula RWG, 1995. The ANTOSTRAT Antarctic Peninsula Regional Working Group digital navigation compilation. In Cooper, A.K., Barker, P.F., and Brancolini, G. (Eds.), Geology and Seismic Stratigraphy of the Antarctic Margin, Antarct. Res. Ser., 68.

Denton, G.H., Sugden, D.E., Marchant, D.R., Hall, B.L., and Wilch, T.I., 1993. East Antarctic ice sheet sensitivity to Pliocene climate change from a Dry Valleys perspective. Geograf. Ann., 75A:155-204.

Doake, C.S., and Vaughan, D.G., 1991. Rapid disintegration of the Wordie Ice Shelf in response to atmospheric warming. Nature, 350:328-330.

Domack, E.W., and McClennen, C.E., 1996. Accumulation of glacial marine sediments in fjords of the Antarctic Peninsula and their use as late Holocene paleoenvironmental indicators. Am. Geophys. Union, Antarct. Res. Ser., 70:135-154.

Domack, E.W., Ishman, S.E., Stein, A.B., McClennen, A.B., and Jull, A.J.T., 1995. Late Holocene advance of the Müller Ice Shelf, Antarctic Peninsula: sedimentologic, paleontologic, and geochemical evidence. Antarct. Sci., 7:159-170.

Domack, E., Jull, A.J.T., and Donahue, D.J., 1991a. Holocene chronology for the unconsolidated sediments at Hole 740A: Prydz Bay, East Antarctica. In Barron, J., Larsen, B., et al., Proc. ODP, Sci. Results, 119: College Station, TX (Ocean Drilling Program), 747-750.

Domack, E.W., Jull, A.J.T., and Nakao, S., 1991b. Advance of East Antarctic outlet glaciers during the Hypsithermal: implications for the volume of the Antarctic Ice Sheet under global warming. Geology, 19:1059-1062.

Drewry, D.J., and Morris, E.M., 1992. The response of large ice sheets to climate change. Philos. Trans. R. Soc. London B., 338:235-242.

Elliot, D.H., 1997. The planar crest of Graham Land, northern Antarctic Peninsula: possible origins and timing of uplift. In Barker, P.F., and Cooper, A.K. (Eds.), Geology and Seismic Stratigraphy of the Antarctic Margin (Pt 2). Antarct. Res. Ser., 71:51-73. 
Escutia, C., Eittreim, S.L., and Cooper, A.K., 1997. Cenozoic sedimentation on the Wilkes Land continental rise, Antarctica. In Ricci, C.A. (Ed.), The Antarctic Region: Geological Evolution and Processes. Init. Results, SEDANO Progr., Terra Antarct., 791795.

Fraser, W.R., Trivelpiece, W.Z., Ainley, D.G., and Trivelpiece, S.G., 1992. Increases in Antarctic penguin populations: reduced competition with whales or a loss of sea ice due to environmental warming? Polar Biol., 11:525-531.

Fryer, P., Pearce, J.A., Stokking, L.B., et al., 1990. Proc. ODP, Init. Repts., 125: College Station, TX (Ocean Drilling Program).

Garrett, S.W., and Storey, B.C., 1987. Lithospheric extension on the Antarctic Peninsula during Cenozoic subduction. In Coward, M.P., Dewey, J.F., and Hancock, P.L. (Eds.), Continental Extensional Tectonics. Geol. Soc. Spec. Publ. London, 28:419-431.

Gersonde, R., Kyte, F.T., Bleil, U., Diekmann, B., Flores, J.A., Gohl, K., Grahl, G., Hagen, R., Kuhn, G., Sierro, F.J., Voelker, D., Abelmann, A., and Bostwick, J. A., 1997. Geological record and reconstruction of the late Pliocene impact of the Eltanin asteroid in the Southern Ocean. Nature, 390:357-363.

Gloersen, P., and Campbell, W.J., 1992. Arctic and Antarctic Sea Ice, 1978-1987: Satellite Passive-Microwave Observations and Analysis. Washington (NASA).

Goodell, H.G., 1964. Marine geology of the Drake Passage, Scotia Sea and South Sandwich Trench. Florida State Univ. Dept. Geol. Contrib. Sedimentol. Res. Lab., 7.

Gordon, A.L., 1966. Potential temperature, oxygen and circulation of bottom water in the Southern Ocean. Deep-Sea Res., 13:1125-1138.

Haq, B.U., Hardenbol, J., and Vail, P.R., 1987. Chronology of fluctuating sea levels since the Triassic. Science, 235:1156-1167.

Harden, S.L., Demaster, D.J., and Nittrouer, C.A., 1992. Developing sediment geochronologies for high-latitude continental shelf deposits: a radiochemical approach. Mar. Geol., 103:69-97.

Hayes, D.E., Frakes, L.A., et al., 1975. Init. Repts., DSDP, 28: Washington (U.S. Govt. Printing Office).

Heezen, B.C., and Hollister, C.D., 1971. The Face of the Deep: New York (Oxford University Press).

Hoffmann, E.E., Klinck, J.M., Lascara, C.M., and Smith, D.A., 1996. Water mass distribution and circulation west of the Antarctic Peninsula and Bransfield Strait. Antarct. Res. Ser., 70:61-80.

Hollister, C.D., Craddock, C., et al., 1976. Init. Repts. DSDP, 35. Washington (U.S. Govt. Printing Office).

Huybrechts, P., 1993. Glaciological modelling of the Late Cenozoic East Antarctic ice sheet: stability or dynamism. Geograf. Ann., 75A:221-238.

Jacobs, S.S., and Comiso, J.C., 1993. A recent sea-ice retreat west of the Antarctic Peninsula. Geophys. Res. Lett., 20:1171-1174.

Kennett, J.P., and Barker, P.F., 1990. Latest Cretaceous to Cenozoic climate and oceanographic development in the Weddell Sea, Antarctica: an ocean-drilling perspective. In Barker, P.F., Kennett, J.P., et al., Proc. ODP, Sci. Results, 113: College Station, TX (Ocean Drilling Program), 937-960.

Kirby, M.E., Domack, E.W., and McClennen, C.E., in press. Magnetic stratigraphy and sedimentology of Holocene marine deposits in the Palmer Deep, Bellingshausen Sea, Antarctica. Mar. Geol.

Kuvaas, B., and Kristoffersen, Y., 1991. The Crary Fan: a trough-mouth fan on the Weddell Sea continental margin, Antarctica. Mar. Geol., 97:345-362.

Kuvaas, B., and Leitchenkov, G., 1992. Glaciomarine turbidite and current-controlled deposits in Prydz Bay, Antarctica. Mar. Geol., 108:365-381.

Kyte, F.T., and Brownlee, D.E., 1985. Unmelted meteoritic debris in the late Pliocene iridium anomaly: evidence for the ocean impact of a nonchondritic asteroid. Geochim. Cosmochim. Acta, 49:1095-1108.

Kyte, F.T., Zhou, Z., and Wasson, J.T., 1981. High noble metal concentrations in a late Pliocene sediment. Nature, 292:417-420. 
Kyte, F.T., Zhou, Z., and Wasson, J.T., 1988. New evidence on the size and possible effects of a late Pliocene oceanic asteroid impact. Science, 24:63-65.

Larter, R.D., and Barker, P.F., 1989. Seismic stratigraphy of the Antarctic Peninsula Pacific margin: a record of Pliocene-Pleistocene ice volume and paleoclimate. Geology, 17:731-734.

Larter, R.D., and Barker, P.F., 1991a. Effects of ridge-crest trench interaction on Antarctic-Phoenix spreading: forces on a young subducting plate. J. Geophys. Res., 96:19583-19607.

Larter, R.D., and Barker, P.F., 1991b. Neogene interaction of tectonic and glacial processes at the Pacific margin of the Antarctic Peninsula. In Macdonald, D.I.M. (Ed.), Sedimentation, Tectonics and Eustasy. Spec. Publ. Int. Assoc. Sedimentol., 12:165186.

Larter, R.D., and Cunningham, A.P., 1993. The depositional pattern and distribution of glacial-interglacial sequences on the Antarctic Peninsula Pacific Margin. Mar. Geol., 109:203-219.

Larter, R.D., Rebesco, M., Vanneste, L.E., Gamboa, L.A.P., and Barker, P.F., 1997. Cenozoic tectonic, sedimentary and glacial history of the continental shelf west of Graham Land, Antarctic Peninsula. In Barker, P.F., and Cooper, A.K. (Eds.), Geology and Seismic Stratigraphy of the Antarctic Margin (Pt. 2). Am. Geophys. Union, Antarct. Res. Ser., 71:1-27.

Leat, P.T., Scarrow, J.H., and Millar, I.L., 1995. On the Antarctic Peninsula batholith. Geol. Mag., 13:399-412.

Leventer, A., Domack, E.W., Ishman, E., Brachfeld, S., McClennen, C.E., and Manley, P., 1996. Productivity cycles of 200-300 years in the Antarctic Peninsula region: understanding linkages among the sun, atmosphere, oceans, sea ice, and biota. Geol. Soc. Am. Bull., 108: 1626-1644.

Lodolo, E., Camerlenghi, A., and Brancolini, G., 1993. A bottom simulating reflector on the South Shetland margin, Antarctic Peninsula. Antarct. Sci. 5:207-210.

Lonsdale, M.J., 1990. The relationship between silica diagenesis, methane, and seismic reflections on the South Orkney microcontinent. In Barker, P.F., Kennett, J.P., et al., Proc. ODP, Sci. Results, 113: College Station, TX (Ocean Drilling program), 2737.

Margolis, S.V., Claeys, P.F., and Kyte, F.T., 1991. Microtektites, microkrystites and spinels from a late Pliocene asteroid impact in the Southern Ocean. Science, 251:1594-1597.

McGinnis, J.P., and Hayes, D.E., 1994. Sediment drift formation along the Antarctic Peninsula. Terra Antart., 1:275-276.

McGinnis, J.P., and Hayes, D.E., 1995. The roles of downslope and along-slope depositional processes: southern Antarctic Peninsula continental rise. In Cooper, A.K., Barker, P.F., and Brancolini, G. (Eds.), Geology and Seismic Stratigraphy of the Antarctic Margin. Am. Geophys. Union, Antarct. Res. Ser., 68:141-156.

Miller, K.G., Fairbanks, R.G., and Mountain, G.S., 1987. Tertiary oxygen isotope synthesis, sea-level history and continental margin erosion. Paleoceanography, 2:1-19.

Mohr, B.A.R., 1990. Eocene and Oligocene sporomorphs and dinoflagellate cysts from Leg 113 drill sites, Weddell Sea, Antarctica. In Barker, P.F., Kennett, J.P., et al., Proc. ODP, Sci. Results, 113: College Station, TX (Ocean Drilling Program), 595-612.

Moyes, A.B., Thomson, J.W., Smellie, J.L., Pankhurst, R.J., Thomson, M.R.A., Griffiths, C.J., Johnson, A.C., Vaughan, D.G., Garrett, S.W., Smith, A.M., Mantripp, D.R., Willan, C.F.H., and King, S., 1994. Geological Map of Adelaide Island to Foyn Coast. BAS Geomap Ser., sheet 3, 1:250,000 with supplementary text. Cambridge, British Antarctic Survey.

Nitsche, F.O., Gohl, K., Vanneste, K., and Miller, H., 1997. Seismic expression of glacially deposited sequences in the Bellingshausen and Amundsen seas, West Antarctica. In Barker, P.F., and Cooper, A.K. (Eds.), Geology and Seismic Stratigraphy of the Antarctic Margin (Pt 2). Antarct. Res. Ser., 71:95-108. 
Nowlin, W.D., Jr., and Zenk, W., 1988. Westward bottom currents along the margin of the South Shetland island arc. Deep-sea Res., 35:269-301.

O'Brien, S.R., Mayewski, P.A., Meeker, L.D., Meese, D.A., Twikler, M., and Witlow, S.I., 1995. Complexity of Holocene climate as reconstructed from Greenland ice core. Science, 270:1962-1964.

Orsi, A.H., Whitworth III, T., and Nowlin, W.D., Jr., 1995. On the meridional extent and fronts of the Antarctic Circumpolar Current. Deep-Sea Res., 42:641-673.

Pope, P.G., and Anderson, J.B., 1992. Late Quaternary glacial history of the northern Antarctic Peninsula's western continental shelf: evidence from the marine record. Am. Geophys. Union, Antarct. Res. Ser., 57:63-91.

Pudsey, C.J., 1992. Late Quaternary changes in Antarctic Bottom Water velocity inferred from sediment grain size in the northern Weddell Sea. Mar. Geol., 107: 933.

Pudsey, C.J., and Camerlenghi, A., 1998. Glacial-interglacial deposition on a sediment drift on the Pacific margin of the Antarctic Peninsula. Antarct. Sci., 10:286308.

Pudsey, C.J., Barker, P.F., and Larter, R.D., 1994. Ice sheet retreat from the Antarctic Peninsula shelf. Continental Shelf Res., 14:1647-1675.

Raisbeck, G.M., Yiou, F., Jouzel, J., and Petit, J.R., 1990. ${ }^{10} \mathrm{Be}$ and ${ }^{2} \mathrm{H}$ in polar ice cores as a probe of the solar variability's influence on climate. Philos. Trans. R. Soc. London A, 330:463-470.

Rebesco, M., Camerlenghi, A., DeSantis, L., Domack, E.W., and Kirby, M.E., 1998. Seismic stratigraphy of Palmer Deep: a fault-bounded Late Quaternary sediment trap on the inner continental shelf, Antarctic Peninsula Pacific margin. Mar. Geol., 151:89-110.

Rebesco, M., Camerlenghi, A., and Zanolla, C., in press. Bathymetry and morphogenesis of the continental margin west of the Antarctic Peninsula. Terra Antarct.

Rebesco, M., Larter, R.D., Barker, P.F., Camerlenghi, A., and Vanneste, L.E., 1994. The history of sedimentation on the continental rise west of the Antarctic Peninsula. Terra Antarct., 1:277-280.

Rebesco, M., Larter, R.D., Barker, P.F., Camerlenghi, A., and Vanneste, L.E., 1997. The history of sedimentation on the continental rise west of the Antarctic Peninsula. In Barker, P.F., and Cooper, A.K. (Eds.), Geology and Seismic Stratigraphy of the Antarctic Margin (Pt. 2). Am. Geophys. Union, Antarctic Res. Ser., 71:29-50.

Rebesco, M., Larter, R.D., Camerlenghi, A., and Barker, P.F., 1996. Giant sediment drifts on the continental rise of the Antarctic Peninsula. Geo-Mar. Lett., 16:65-75.

Reynolds, J.M., 1981. The distribution of mean annual temperatures in the Antarctic Peninsula. Br. Antarct. Surv. Bull., 54:123-133.

Ridley, J., 1993. Surface melting on Antarctic Peninsula ice shelves detected by passive microwave sensors. Geophys. Res. Lett., 30:2639-2642.

Sahagian, D.L., and Watts, A.B., 1991. Introduction to the Special Section on measurement, causes and consequences of long-term sea level changes. J. Geophys. Res., 96:6585-6589.

Saunders, A.D., Tarney, J., and Weaver, S.D., 1980. Transverse geochemical variations across the Antarctic Peninsula: implications for the genesis of calc-alkaline magmas. Earth Planet. Sci. Lett., 46:344-360.

Scuderi, L.A., 1993. A 2000-year tree ring record of annual temperatures in the Sierra Nevada Mountains. Science, 259:1433-1436.

Shabtaie, S., and Bentley, C.R., 1987. West Antarctic ice streams draining into the Ross Ice Shelf: configuration and mass balance. J. Geophys. Res., 92:1311-1336.

Shimmield, G., Derrick, S., Mackensen, A., Grobe, H., and Pudsey, C., 1993. The history of barium, biogenic silica and organic carbon accumulation in the Weddell Sea and Antarctic Ocean over the last 150,000 years. In Zahn, R., Pedersen, T.F., Kaminski, M.A., and Labeyrie, L. (Eds.), Carbon Cycling in the Glacial Ocean: Constraints on the Ocean's Role in Global Change: quantitative approaches in paleoceanography. Heidelberg (Springer), 555-574. 
Skvarca, P., 1993. Fast recession of the northern Larsen Ice Shelf monitored by space images. Ann. Glaciol., 17:317-321.

Sloan, B.J., Lawver, L.A., and Anderson, B.J., 1995. Seismic stratigraphy of the Larsen Basin, eastern Antarctic Peninsula. In Cooper, A.K., Barker, P.F., and Brancolini, G. (Eds.), Geology and Seismic Stratigraphy of the Antarctic Margin: Antarct. Res. Ser., 68:59-74.

Smellie, J.L., Pankhurst, R.J., Hole, M.J., and Thomson, J.W., 1988. Age, distribution and eruptive conditions of late Cenozoic alkaline volcanism in the Antarctic Peninsula and Eastern Ellsworth Land: a review. Bull. Br. Antarct. Surv., 80:21-49.

Smith, R.I.L., 1994. Vascular plants as bio-indicators of regional warming in Antarctica. Oecologia, 99:322-328.

Taylor, B., Fujioka, K., et al., 1990. Proc. ODP, Init. Repts., 126: College Station, TX (Ocean Drilling Program).

Tomlinson, J.S., Pudsey, C.J., Livermore, R.A., Larter, R.D., and Barker, P.F., 1992. GLORIA survey of the Pacific margin of the Antarctic Peninsula: tectonic fabric and sedimentary processes. In Yoshida, Y., Kaminuma, K., and Shiraishi, K. (Eds.), Recent Progress in Antarctic Earth Science: Tokyo (Terra Publ.), 423-429.

Vanneste, L.E., and Larter, R.D., 1995. Deep-tow boomer survey on the Antarctic Peninsula Pacific margin: an investigation of the morphology and acoustic characteristics of Late Quaternary sedimentary deposits on the outer continental shelf and upper slope. In Cooper, A.K., Barker, P.F., and Brancolini, G. (Eds.), Geology and Seismic Stratigraphy of the Antarctic Margin. Am. Geophys. Union, Antarct. Res. Ser., 68:97-121.

Webb, P.-N., and Harwood, D.M., 1991. Late Cenozoic glacial history of the Ross Sea Embayment, Antarctica. Quat. Sci. Rev., 10:215-223.

Wigley, T.M.L., 1988. The climate of the last 10,000 years and the role of the sun. In Stephenson, F.R., and Wolfandale, A.W. (Eds.), Secular Solar and Geomagnetic Variations in the last 10,000 years: Dordrecht (Kluwer), 209-224.

Wise, S.W., Jr., Breza, J.R., Harwood, D.M., and Zachos, J.C., 1992. Paleogene glacial history of Antarctica in light of Leg 120 drilling results. In Wise, S.W., Schlich, R., et al., Proc. ODP, Sci. Res., 120: College Station, TX (Ocean Drilling Program), 10011030.

Zwally, H.J., Comiso, J.C., and Gordon, A.L., 1985. Antarctic offshore leads and polynyas and oceanographic effects. Antarct. Res. Ser., 43:203-255. 
P.F. BArker, A. Camerlenghi

Chapter 2, An Approach to Antarctic glacial History

Figure F1. The dependence of ice-sheet volume upon mean annual temperature $(\mathrm{K})$ at sea level around the coastline and the geographic distribution of an ice sheet stable at each of a series of mean annual temperatures $(5,9,10,15,19$, and 20 Kelvin [K]) above present (location of ANTOSTRAT-based drilling proposals starred). From Huybrechts (1993).
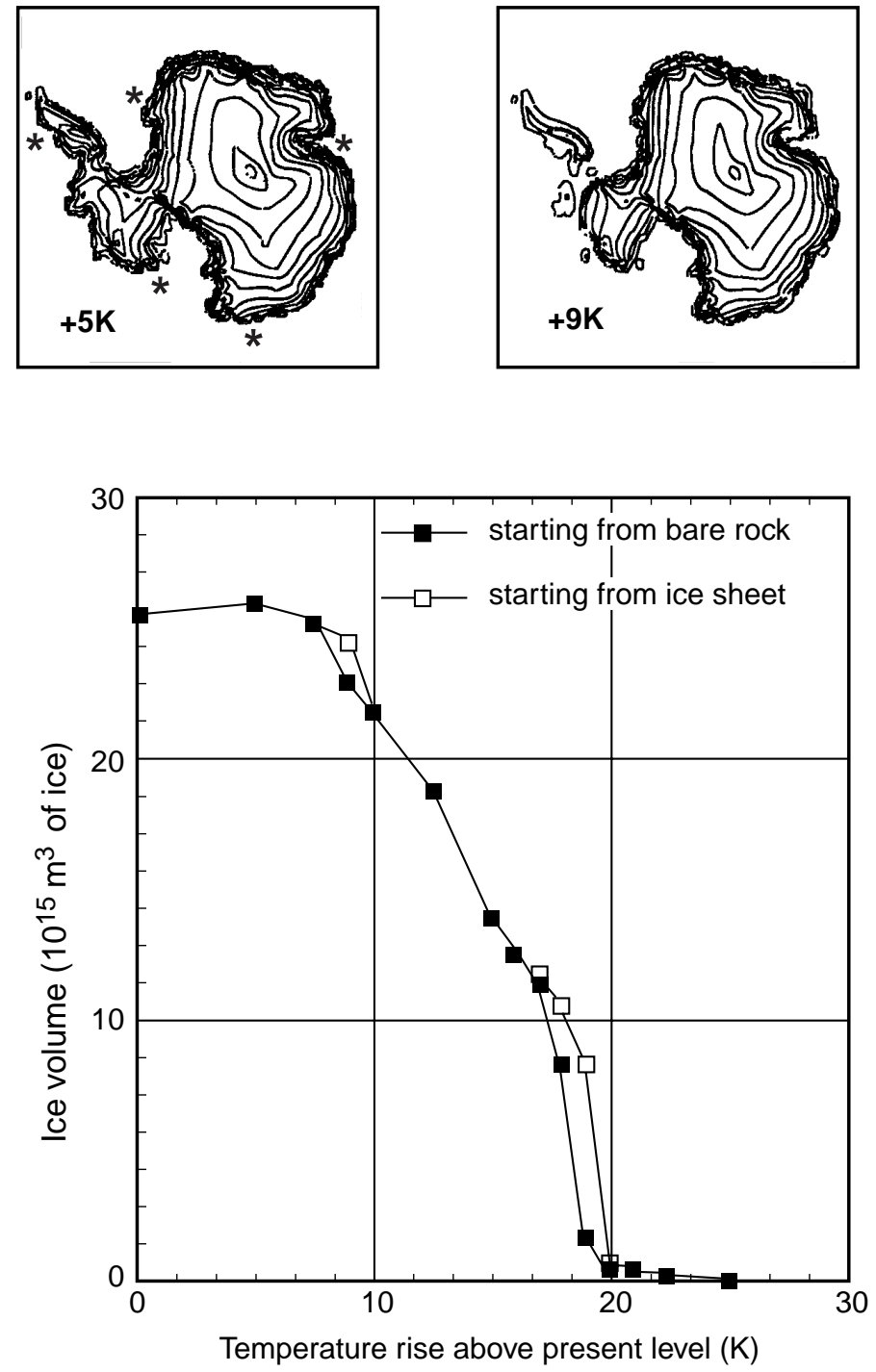
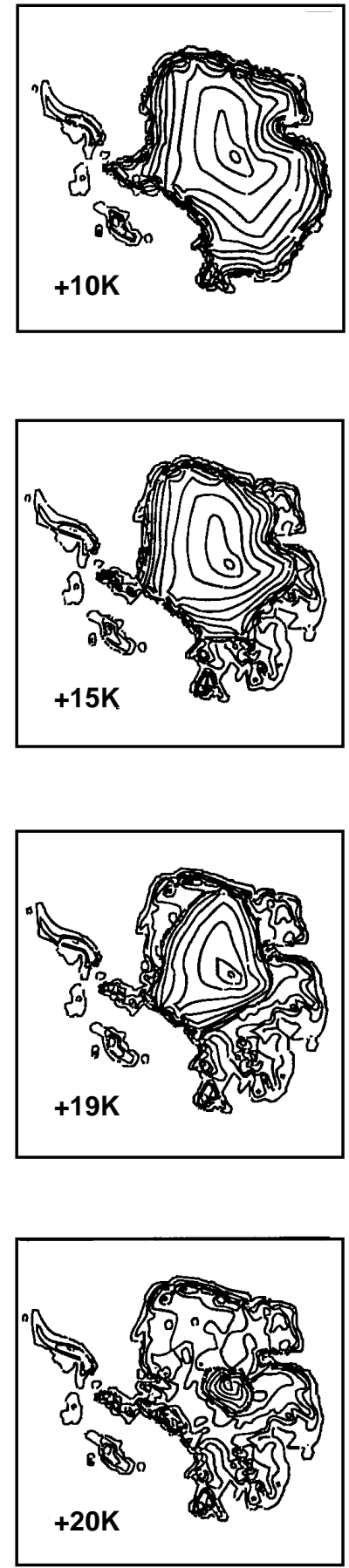
P.F. BArker, A. Camerlenghi

Figure F2. Sequence model of deposition on shelf and slope through a glacial cycle (adapted from Larter and Barker, 1989, 1991b). Unsorted till is deposited on the slope (foresets) during glacial maxima and on the shelf (topsets) during retreat. Pelagic or hemipelagic sediment is deposited on the shelf, slope and rise during interglacials. With re-advance, some or all shelf topsets may be eroded.

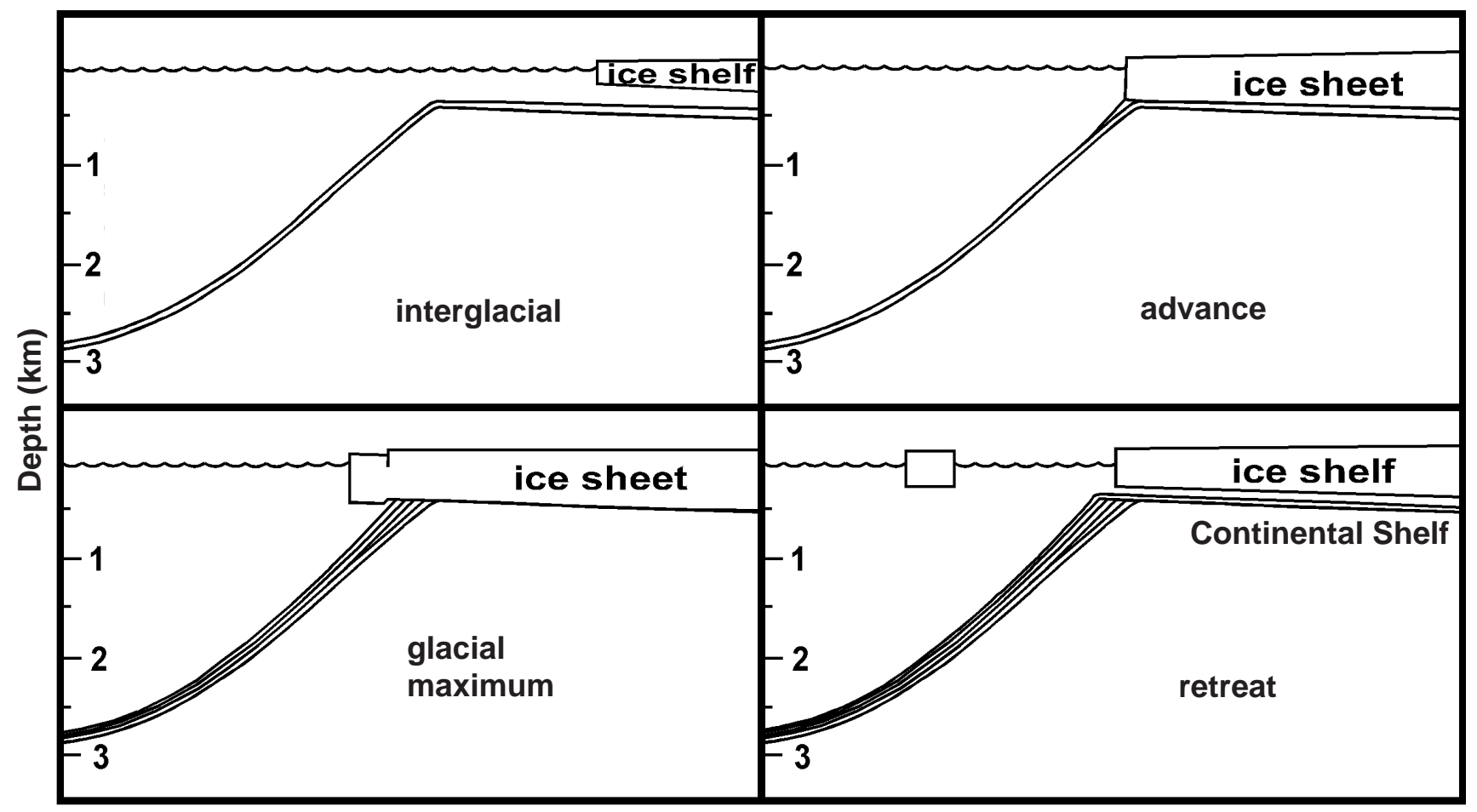


Figure F3. Schematic drawing of the processes active during glacial half-cycles, leading to the development of hemipelagic sediment drifts on the continental rise (adapted from Rebesco et al., 1997). The unstable component of unsorted upper-slope deposits forms first a slump and debris flow, sourcing a turbidity current. Its fine fraction is suspended and entrained in ambient bottom currents to be deposited downcurrent. Drifts are built above the level of the turbidity current channels because (in the case of the Antarctic Peninsula margin and perhaps elsewhere) subsequent turbidity currents erode the deposited sediment everywhere except upon the drifts, maintaining the steeper drift slopes at the limit of stability.

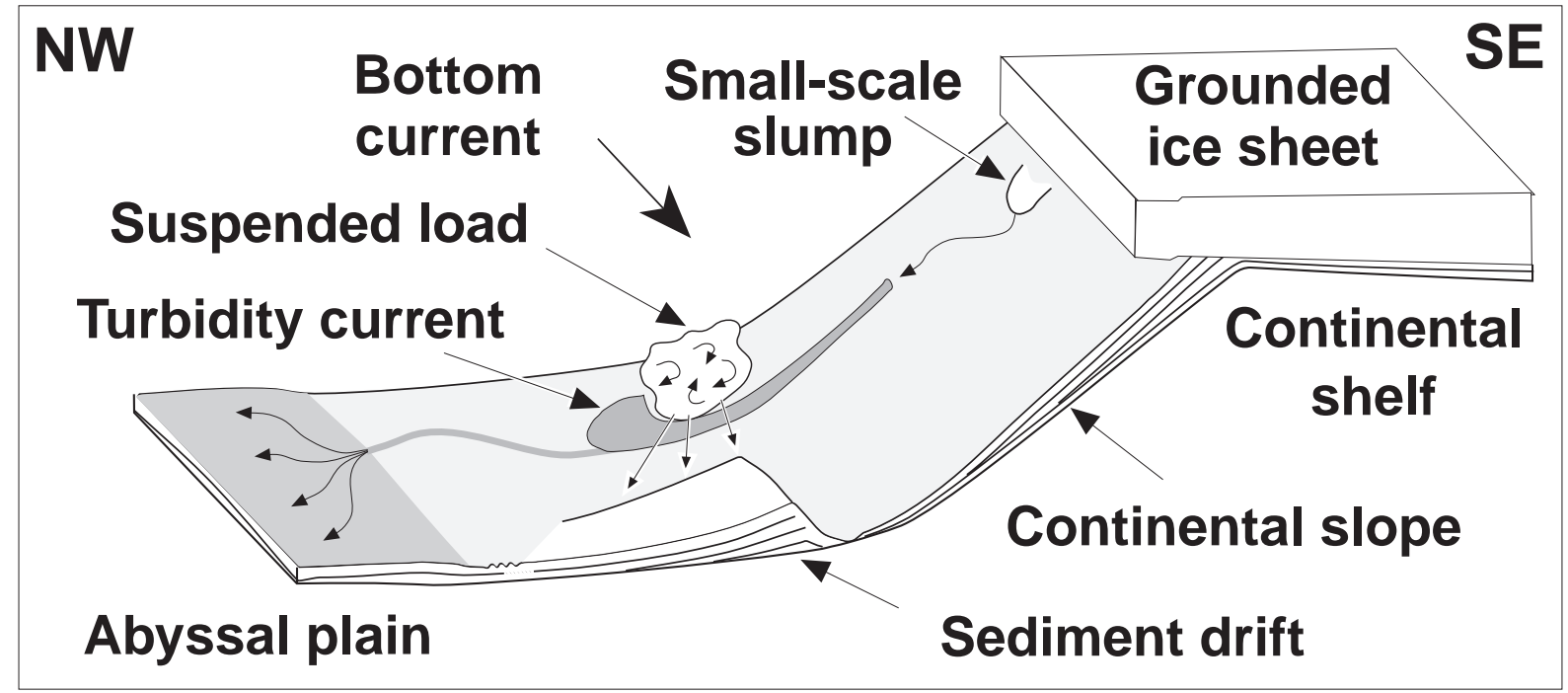


Figure F4. Head of Lallemand Fjord showing flat, possibly peneplanated Antarctic Peninsula plateau with thin ice cover, draining through steep ice falls to a short glacier grounded at the head of a dissecting fjord (reproduced with permission of the British Antarctic Survey).

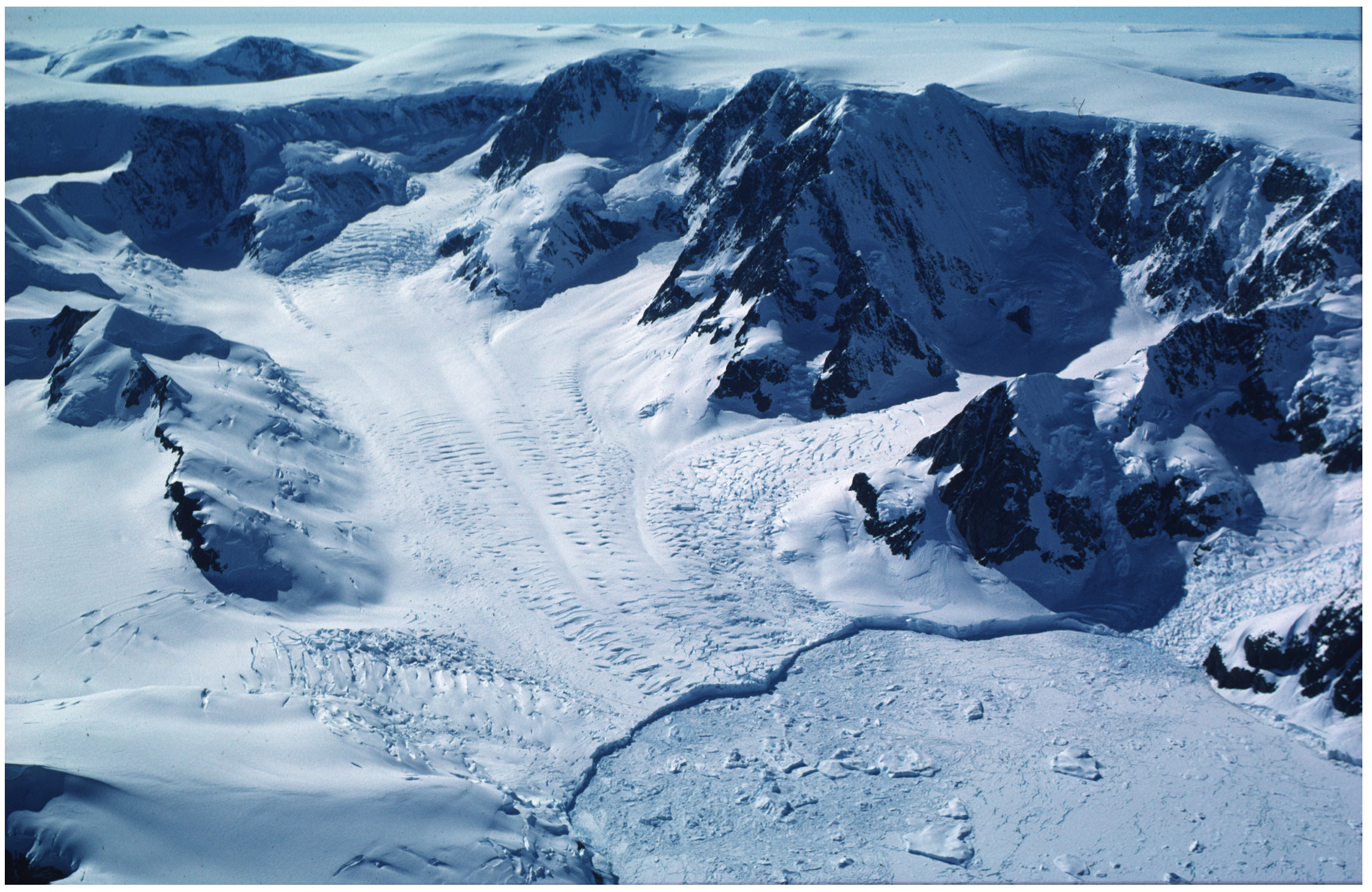


P.F. Barker, A. Camerlenghi

Chapter 2, An Approach to Antarctic Glacial History

Figure F5. Bathymetric chart of the Antarctic Peninsula Pacific margin with Leg 178 sites marked. Also noted is the position of the CTD section shown in Figure F6, p. 34 (after Rebesco et al., in press).

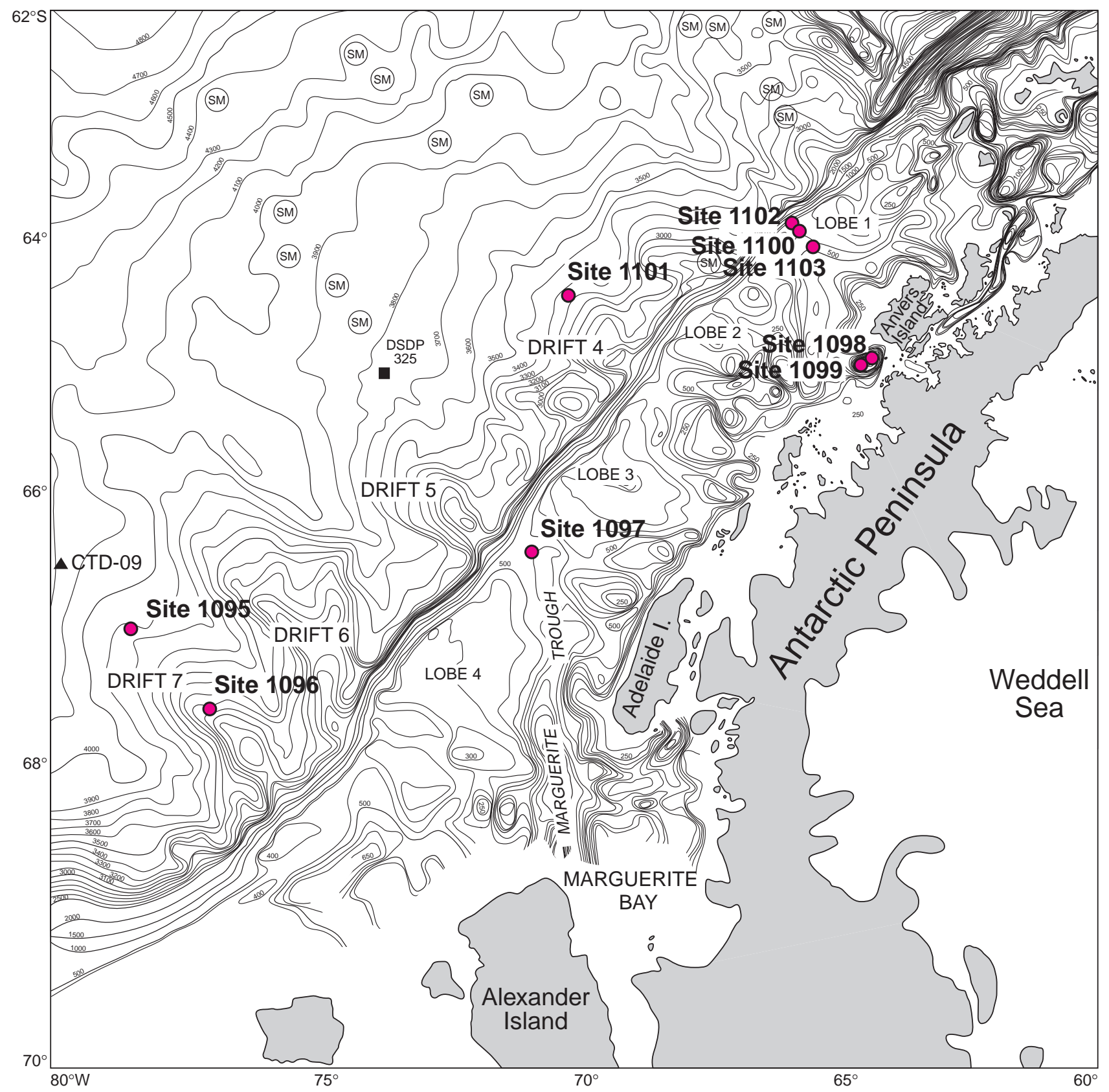


P.F. BArker, A. Camerlenghi

Chapter 2, An Approach to Antarctic glacial History

Figure F6. CTD temperature and salinity profile, station CTD-09 on the Antarctic Peninsula continental rise, with water masses labeled (boundaries between water masses are tentatively marked by dashed lines). Station located in Figure F5, p. 33. Data are unpublished and under analysis (A. Crise, pers. comm., 1998).

SALINITY (\%)

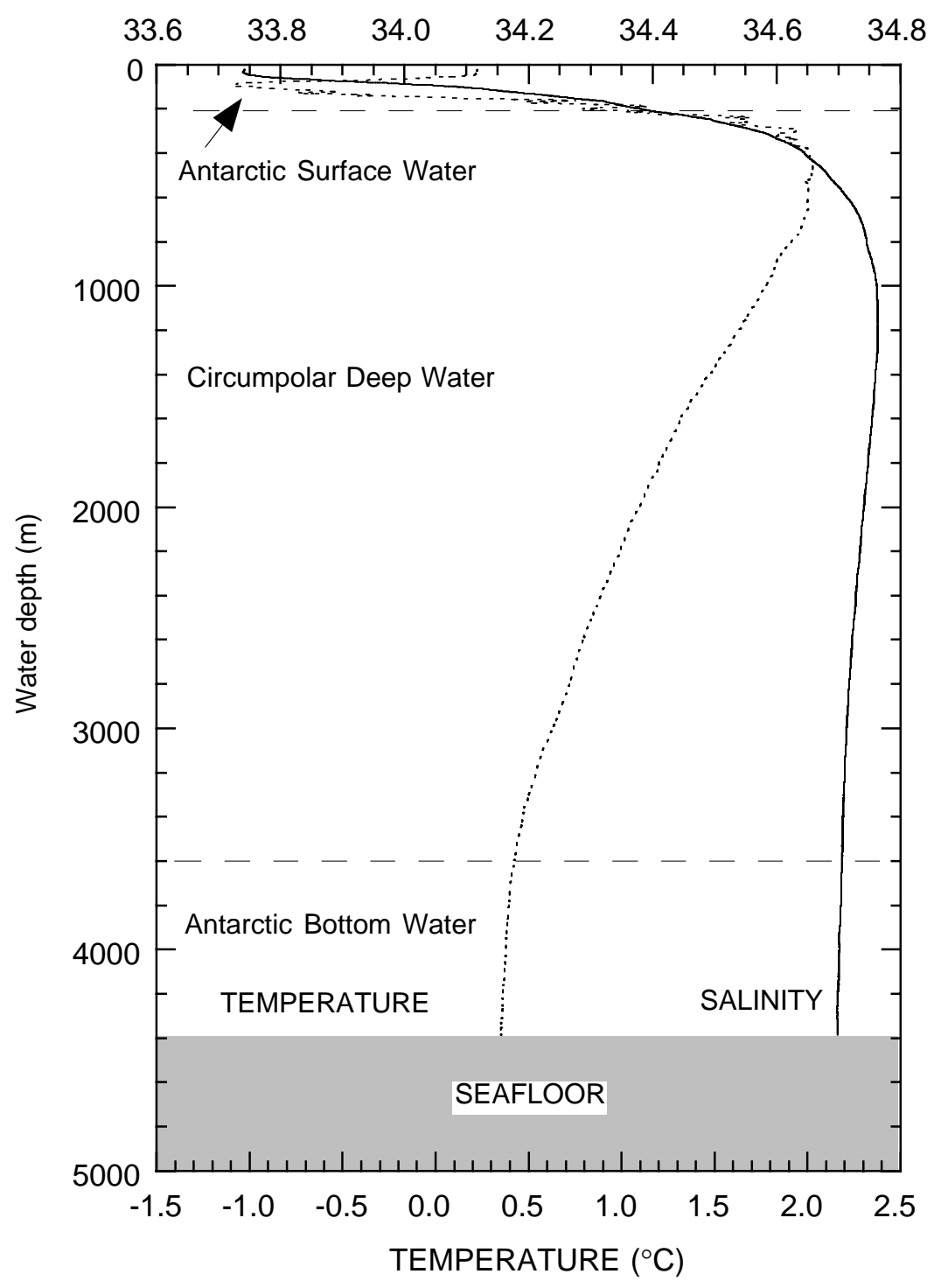




\section{P.F. BArker, A. Camerlenghi}

Figure F7. Ages of ocean floor and ridge crest-trench collisions along the Antarctic Peninsula Pacific margin with drill sites marked (based on the time scale of Cande and Kent [1995] and redrawn from Larter et al. [1997], with additions from Barker [1982] and GEOSAT data). Mid-shelf high and shelf basins taken from Figure F11, p. 39.

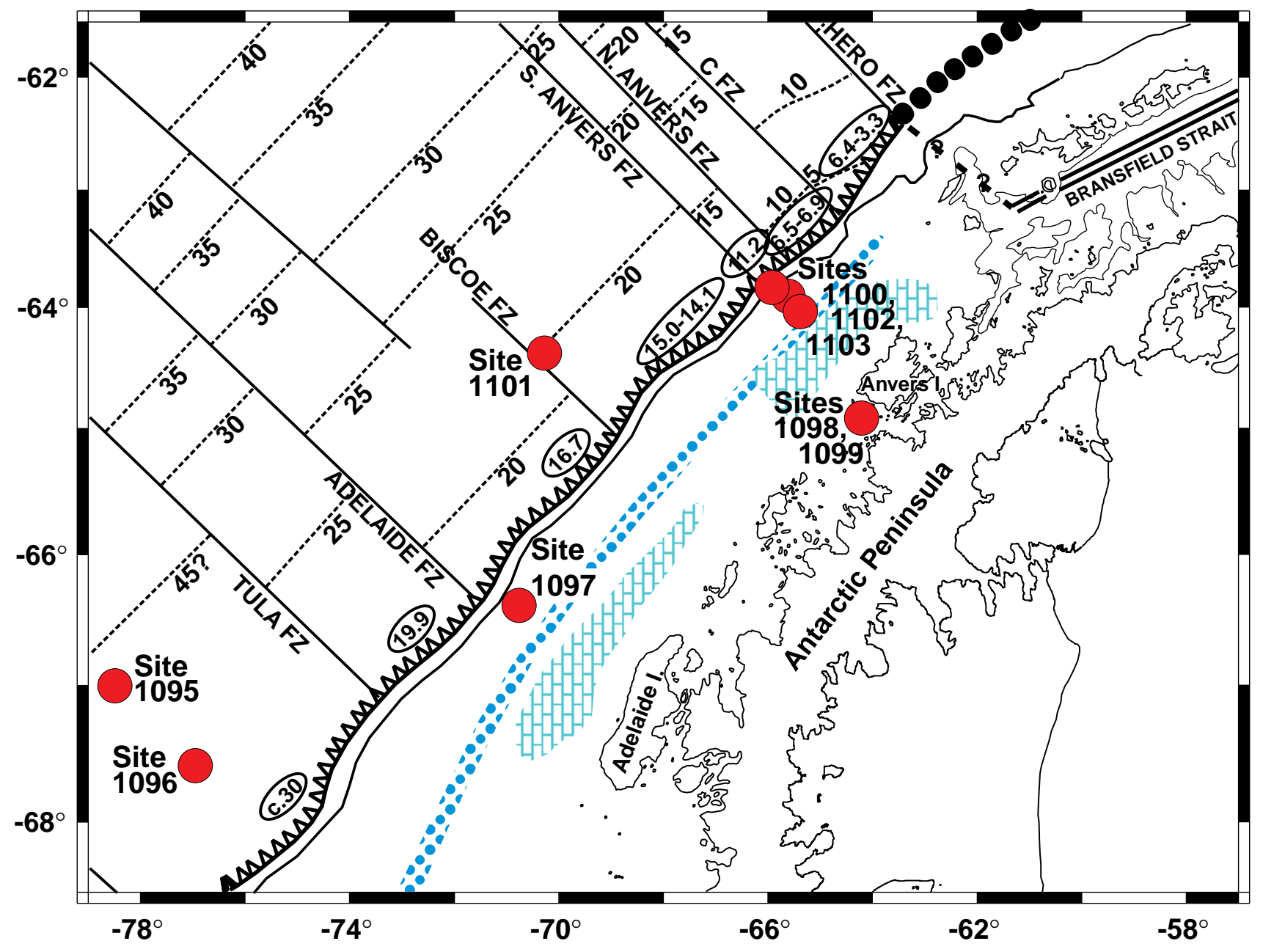




\section{P.F. BARKer, A. CAMErLenghi}

Figure F8. GEOSAT GM mission satellite-derived free-air gravity map of the Antarctic Peninsula and southeast Pacific. Progradational Lobes L1 through L4 at the peninsular shelf edge are prominent gravity highs. A lesser linear anomaly marks the mid-shelf high. On the continental rise, the larger hemipelagic drift mounds also form gravity highs because of their bathymetric expression (compare Figs. F5, p. 33; F7, p. 35; and F11, p. 39).

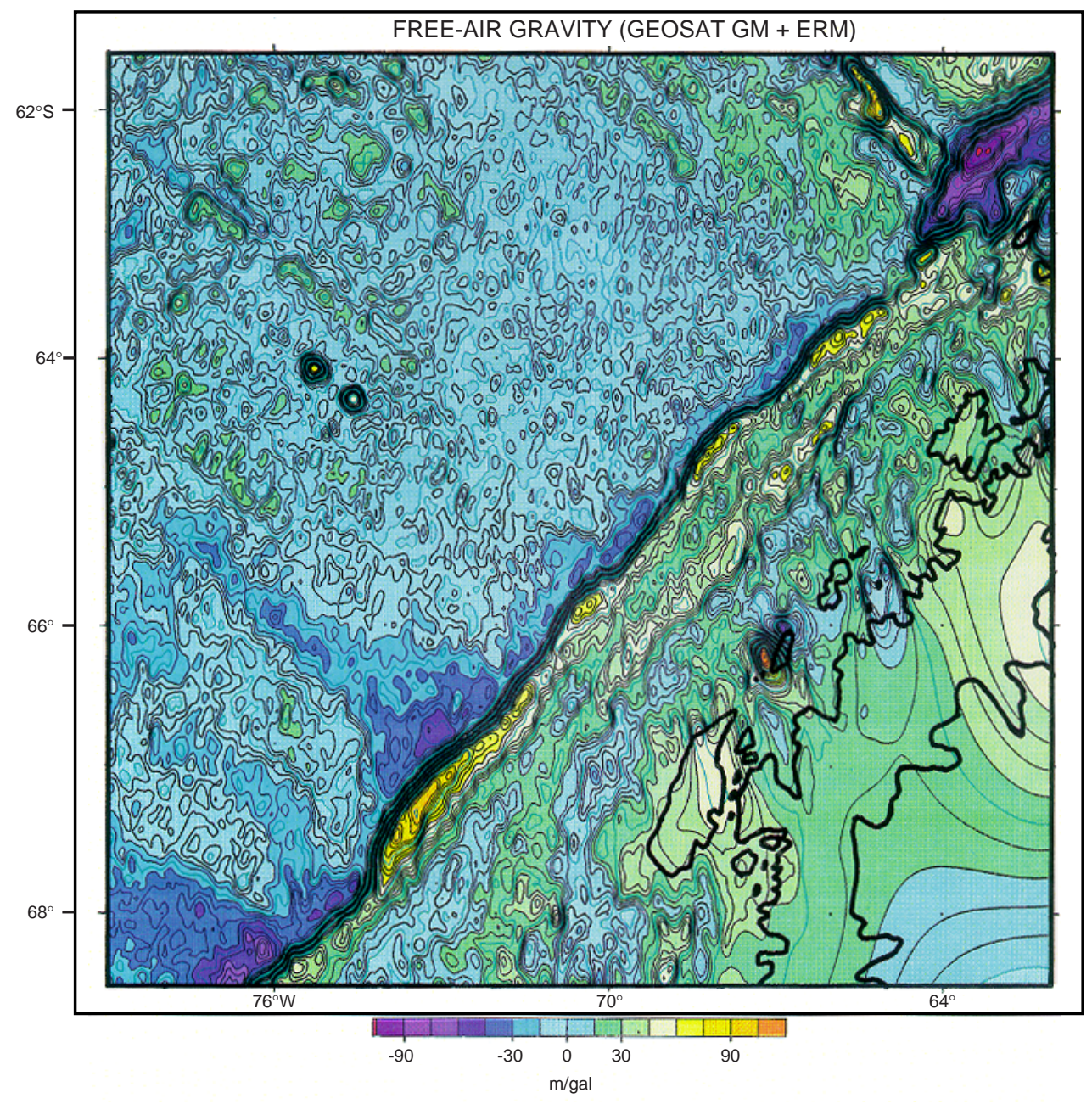


Figure F9. Inner-shelf basin in Lobe 1 area, on seismic profile AI95-149, with mid-shelf high to the northwest. Southeast basin margin sediments are thicker and older, and northwest margin sediments are younger. The northwest basin margin is faulted. This suggests deposition before and during MSH uplift. Vertical exaggeration = 9.5:1. S.P. = shotpoint.

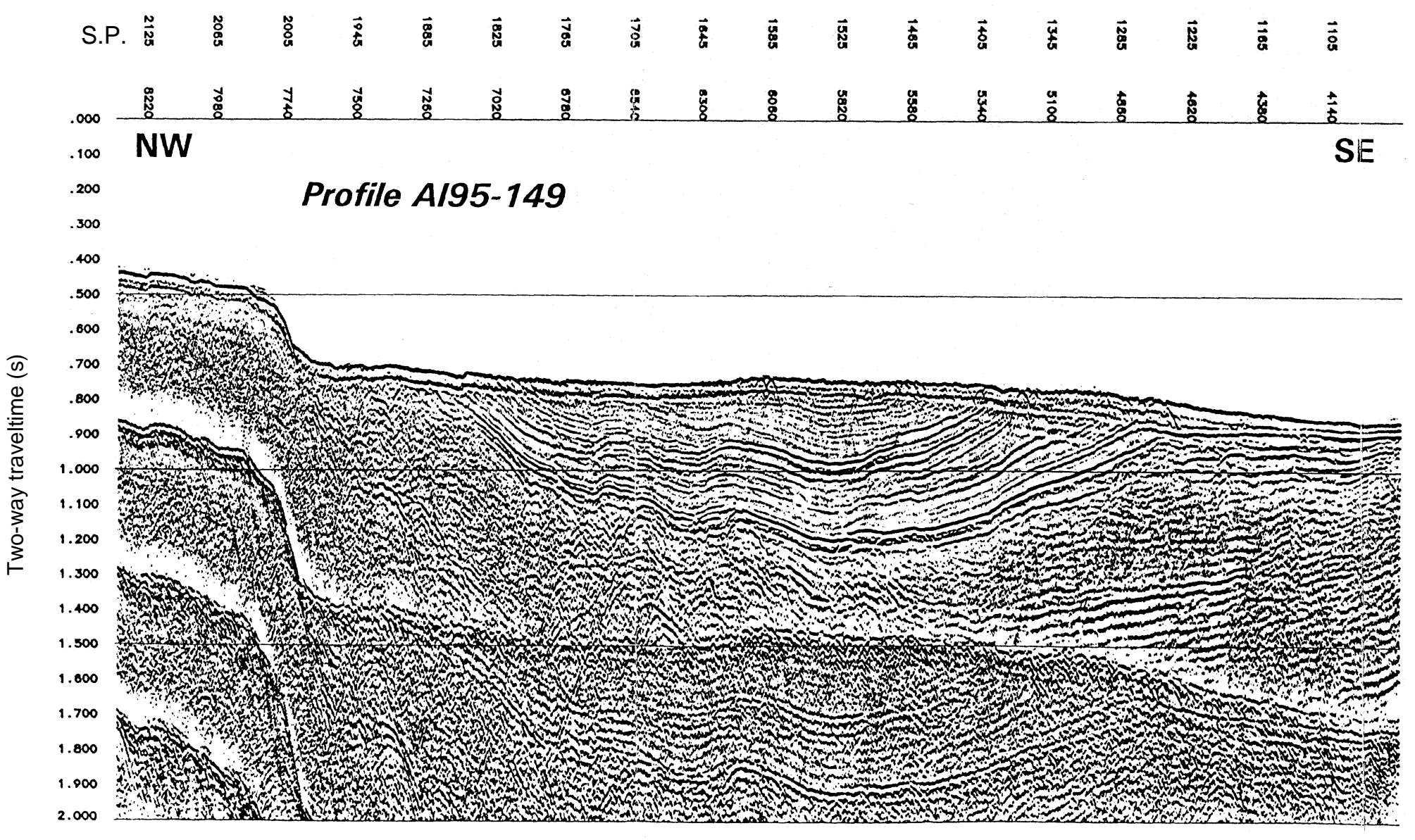


P.F. BArker, A. CAMERlenghi

Chapter 2, An Approach to Antarctic glacial History

Figure F10. Composite track chart of multichannel and single-channel seismic data used in selecting drill sites (ANTOSTRAT Antarctic Peninsula Regional Working Group, revised from Cunningham et al., 1995).

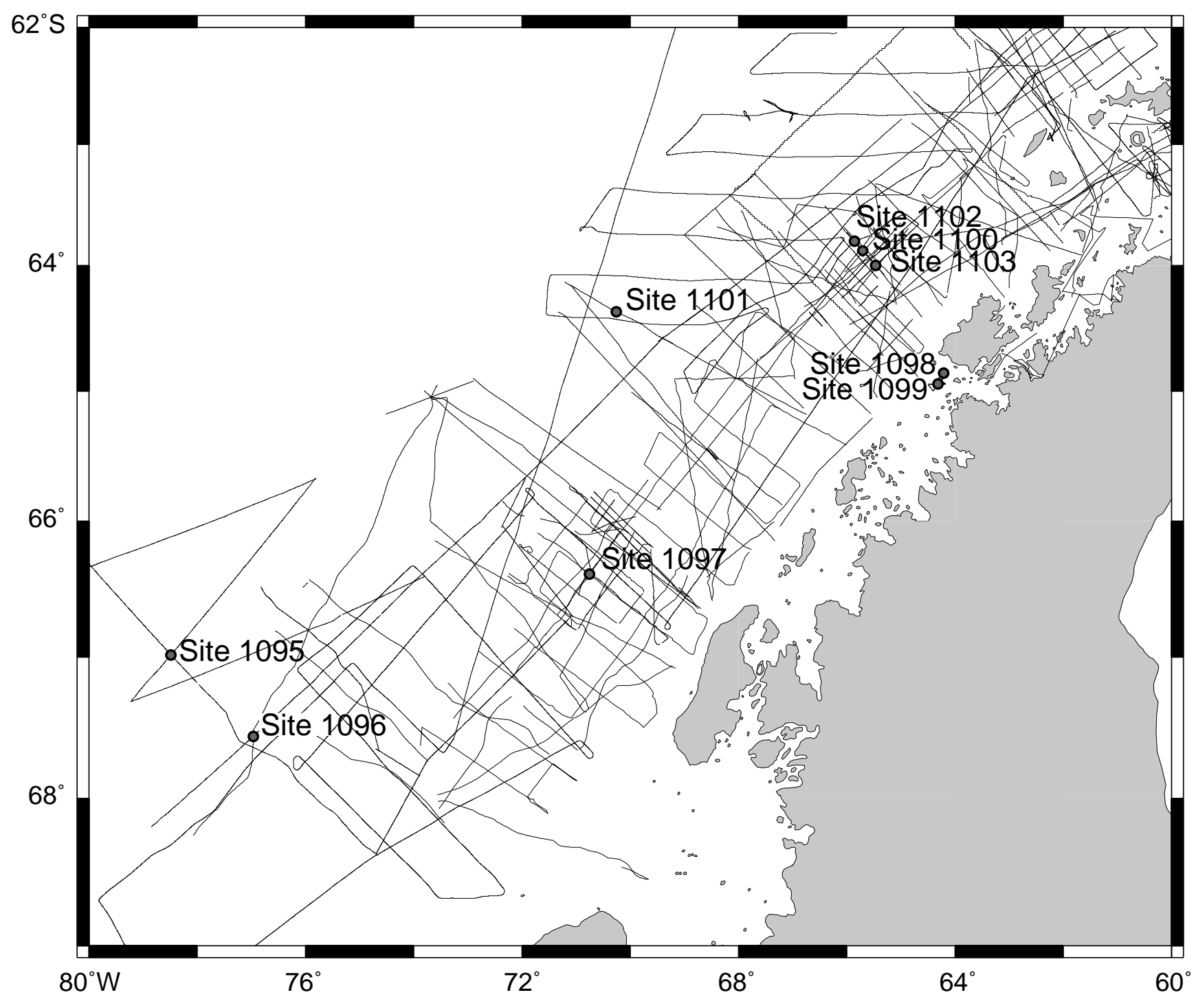


P.F. BArker, A. Camerlenghi

Chapter 2, An Approach to Antarctic glacial History

Figure F11. Schematic figure of tectonic and glacial elements of the Antarctic Peninsula margin and sites drilled during Leg 178 (revised from Barker, 1995a).

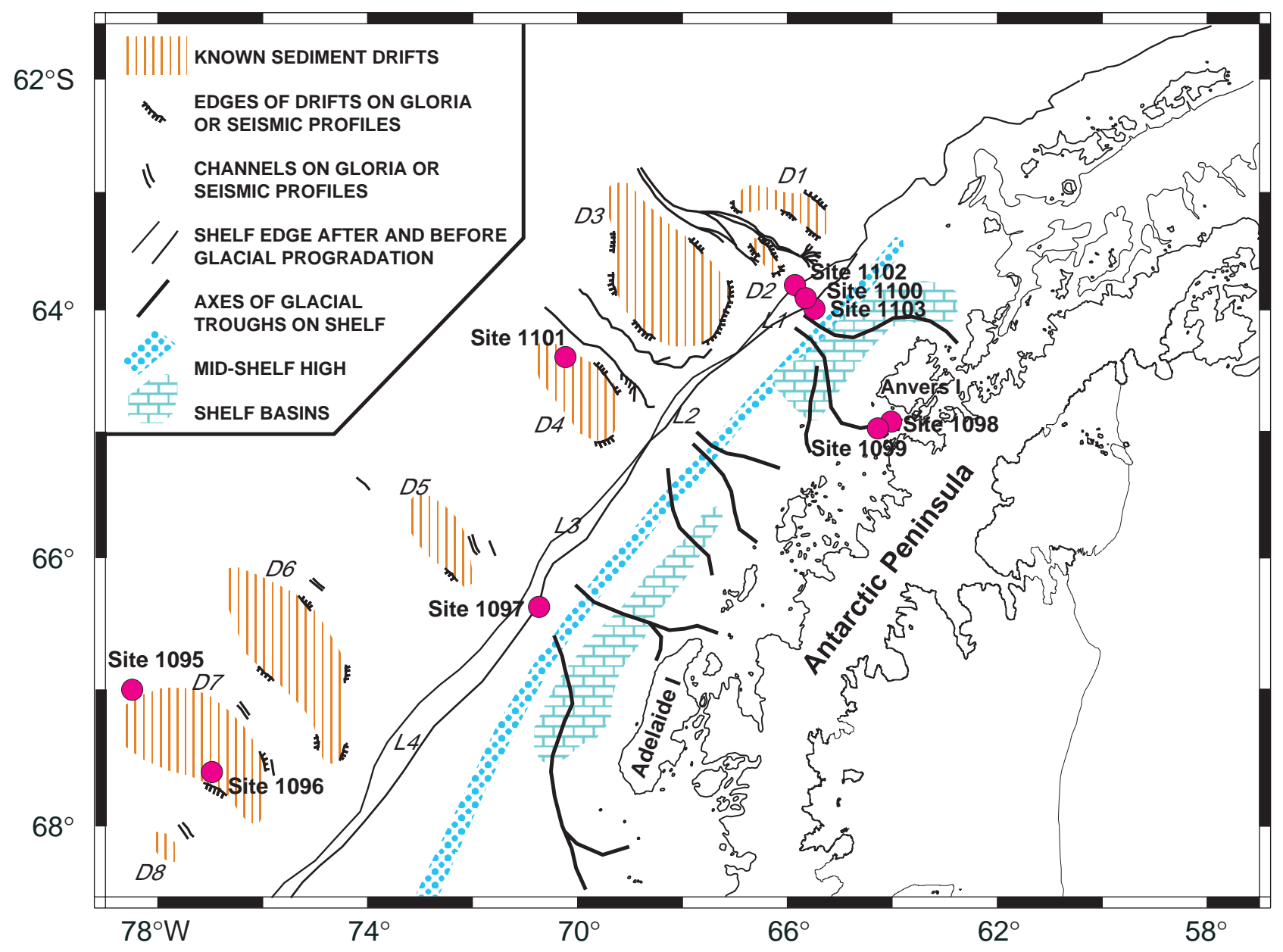


P.F. BArker, A. Camerlenghi

Chapter 2, An Approach to Antarctic glacial History

Figure F12. Line drawing of MCS profile AMG 845-08 from the Antarctic Peninsula margin, showing glacial Sequence Groups S1 and S2 overlying "preglacial" Sequence Group S3, and S4 (Larter and Barker, 1989, 1991b; Barker, 1995a). S1 and S2 are built from glacial sequence units shown schematically in Figure F2, p. 30. (See also "Appendix," p. 24, and Fig. AF1, p. 59, both in the "Leg 178 Summary" chapter).

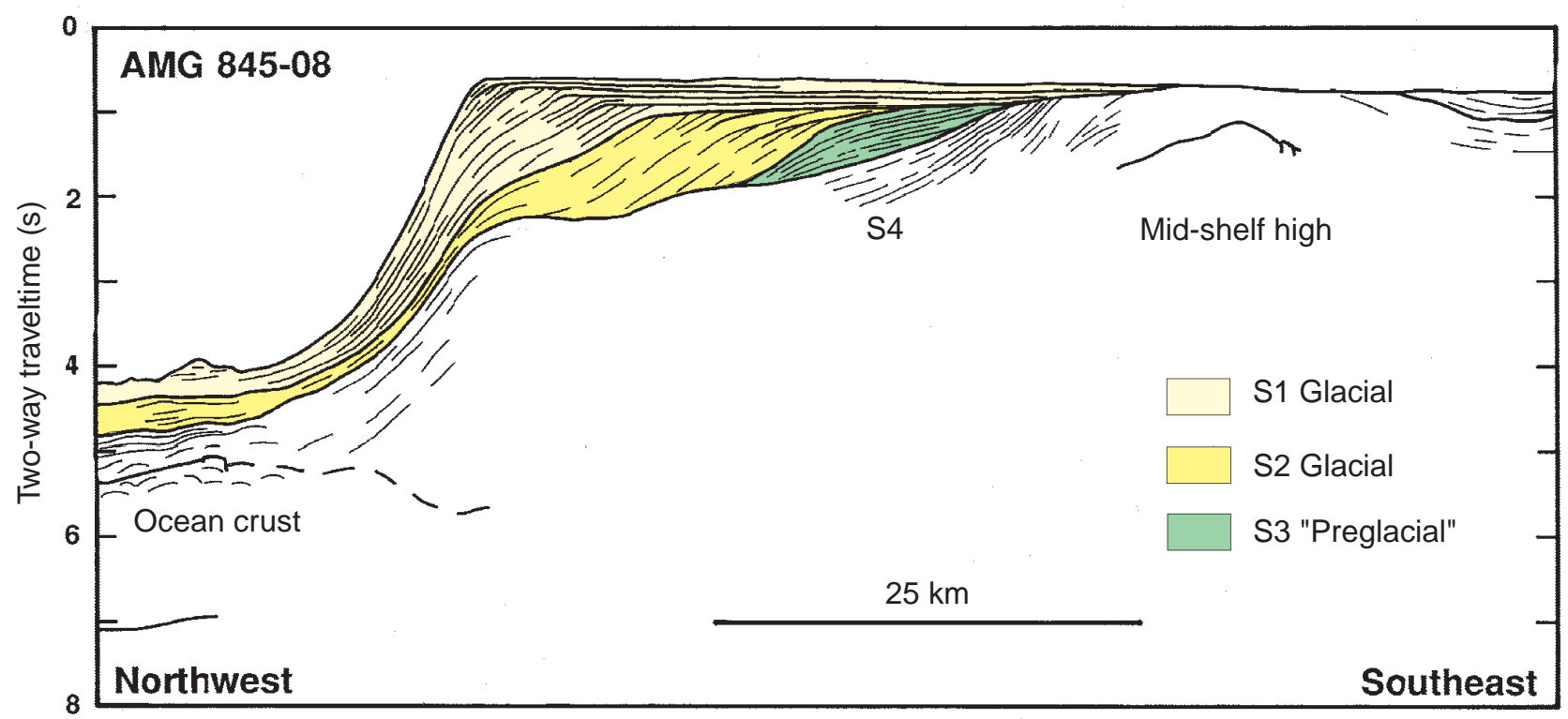


Figure F13. A. Line drawing of deep-tow boomer profile of part of the outer continental shelf off Anvers Island (Vanneste and Larter, 1995). B. Expanded profile showing the seaward frontal slope of a young till body and reflections from underlying bodies. Note the scale of the frontal slope, the slope-parallel internal reflectors (arrowed), and the roughness of the upper surface of the till away from the slope (a result of iceberg plowing).

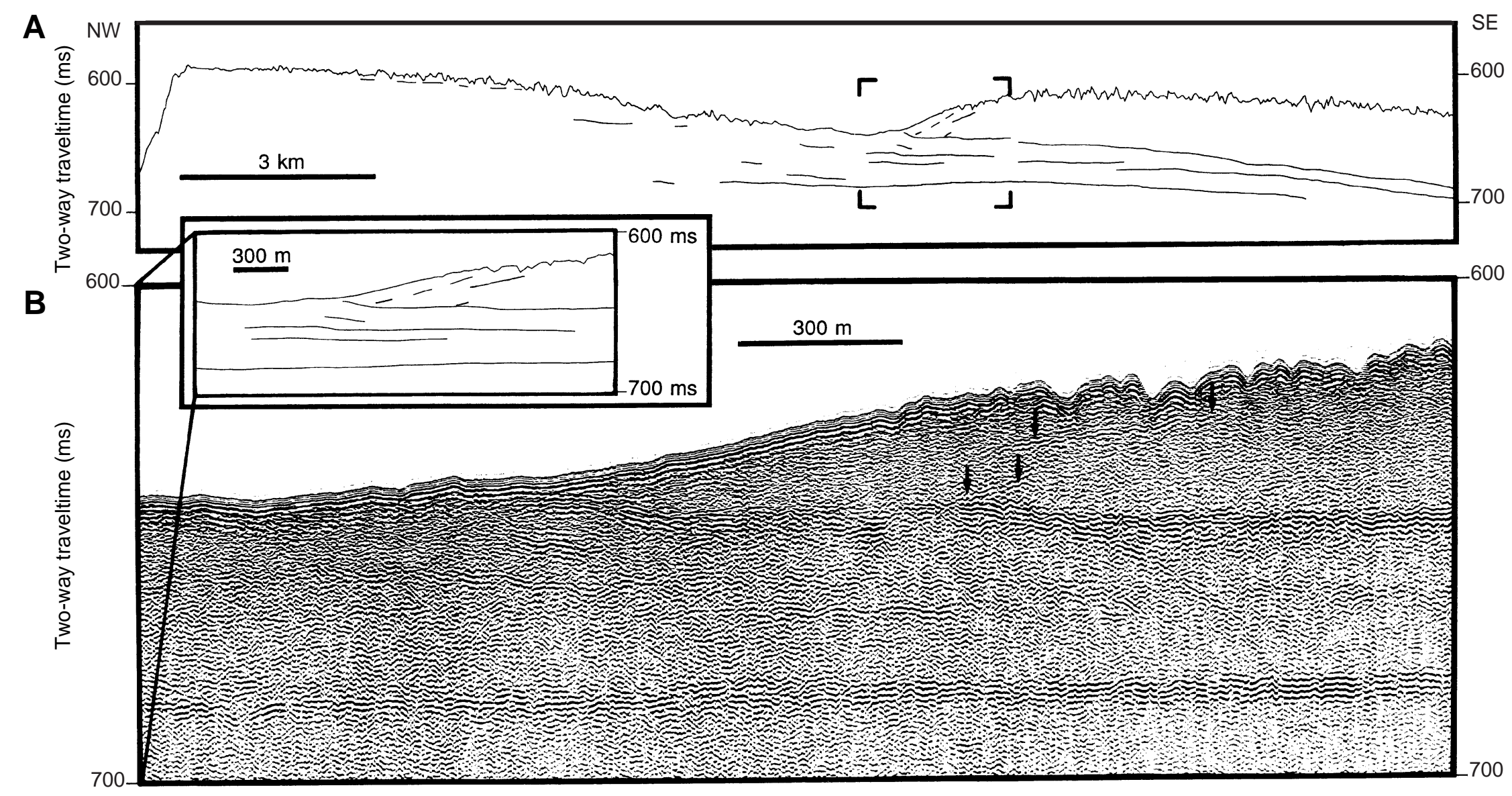


Figure F14. MCS profile IT92-109 through Drift 7 (after Rebesco et al., 1996) with Site 1096 position marked. BSR = bottom-simulating reflector, S.P. = shotpoint.

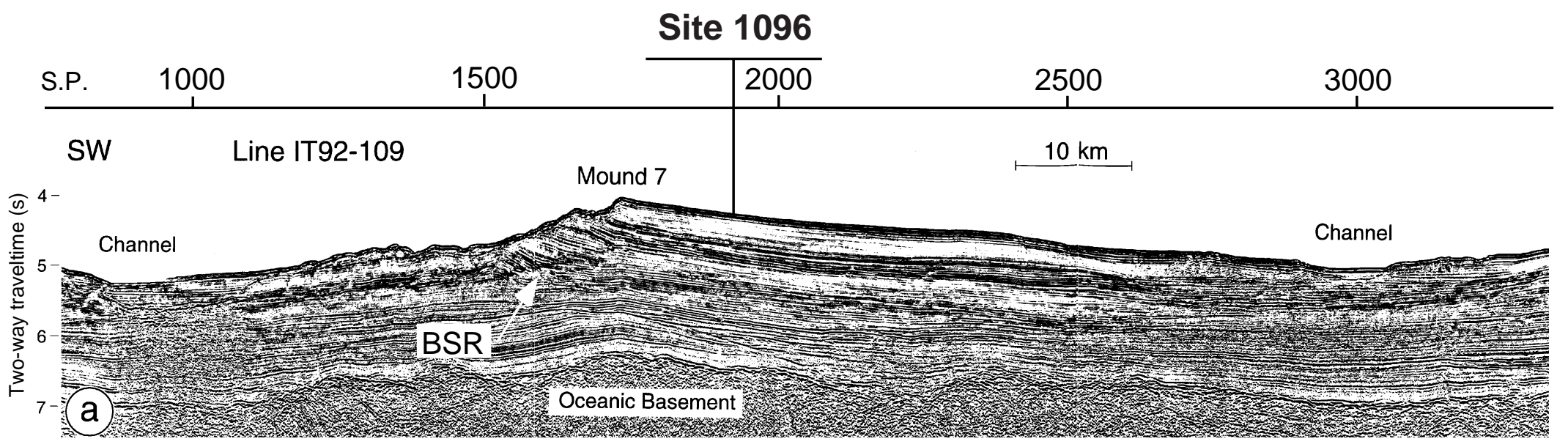


P.F. BArker, A. Camerlenghi

Chapter 2, An Approach to Antarctic glacial History

Figure F15. Line drawing of GLORIA survey of the northeastern Drifts D1 through D4 and intervening Channels I through IV (redrawn from Tomlinson et al., 1992), including the position of Site 1101 on Drift D4.

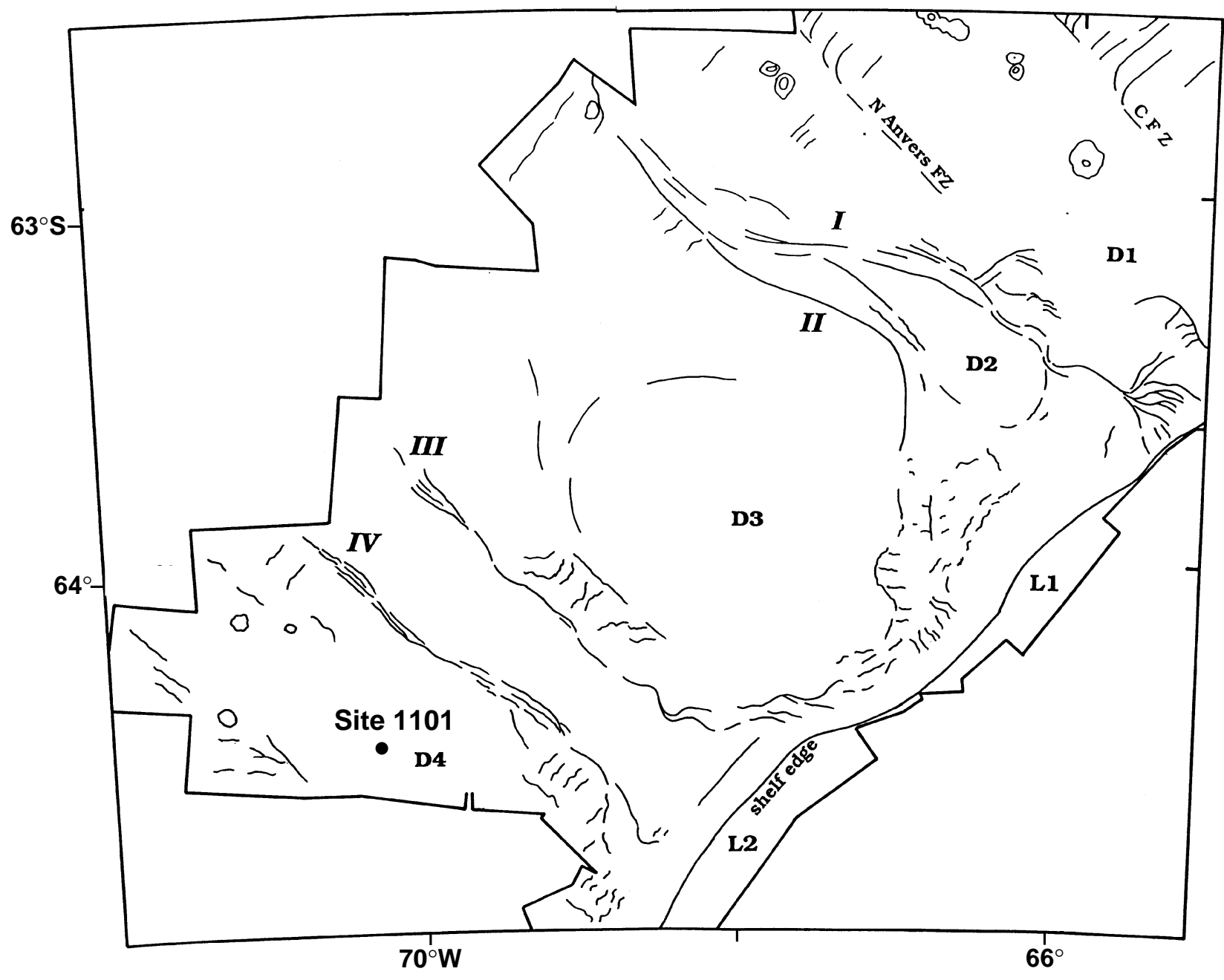


P.F. BArker, A. Camerlenghi

Chapter 2, An Approach to Antarctic glacial History

Figure F16. Magnetic susceptibility from marine sediment core from Palmer Deep (PD92-30, Basin I [Leventer et al., 1996]). The time scale of the sediment core is obtained by ${ }^{14} \mathrm{C}$ ages corrected to calendar year according to O'Brien et al. (1995) and tied to the present and the 2500-yr datum.

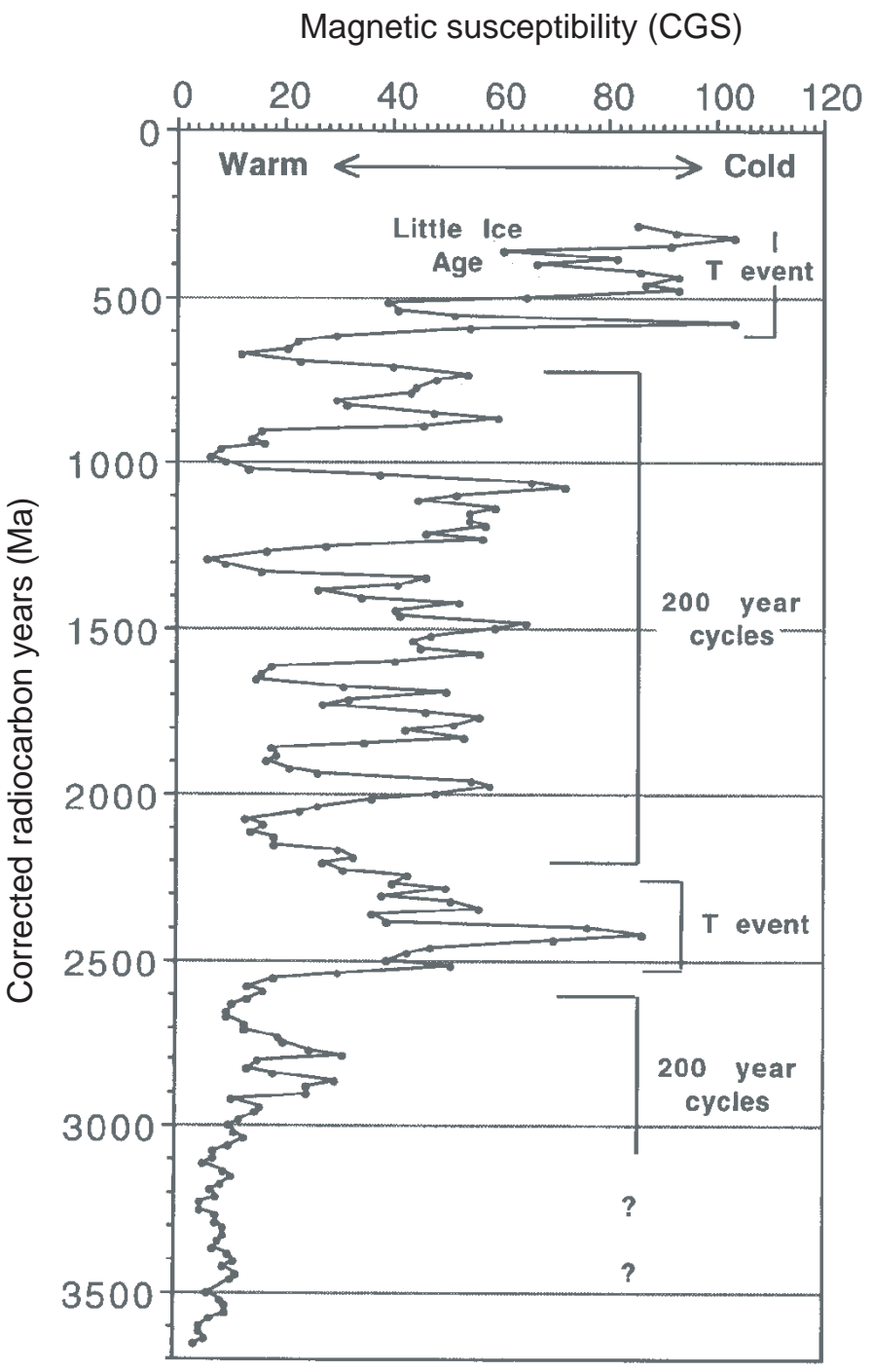

